Article

\title{
Evaluation of Recycled Materials as Hydroponic Growing Media
}

\author{
Nicole Kennard ${ }^{1, *,+} \mathbb{D}$, Ross Stirling ${ }^{2} \mathbb{D}$, Ankush Prashar ${ }^{1}$ and Elisa Lopez-Capel ${ }^{1, *}$ \\ 1 School of Natural and Environmental Sciences, Agriculture Building, Newcastle University, \\ Newcastle upon Tyne NE1 7RU, UK \\ 2 School of Engineering, Drummond Building, Newcastle University, Newcastle upon Tyne NE1 7RU, UK; \\ Ross.Stirling@newcastle.ac.uk \\ * Correspondence: njkennard1@sheffield.ac.uk (N.K.); elisa.lopez-capel@newcastle.ac.uk (E.L.-C.); \\ Tel.: +44-191-2086928 (E.L.-C.) \\ + Present address: Department of Chemistry, Dainton Building, The University of Sheffield, Brook Hill, \\ Sheffield S3 7HF, UK.
}

Received: 18 June 2020; Accepted: 24 July 2020; Published: 28 July 2020

\begin{abstract}
Conventional soilless growing media, such as perlite, are mined from nonrenewable resources and can only be disposed of in landfills after limited use. There is a need to investigate novel, sustainable growing media adapted from waste or engineered to be reused over multiple cycles. This study investigated waste almond shells and a recycled plastic drainage plank as hydroponic growing media alternatives. Physiochemical properties were evaluated, and a germination and greenhouse growth trial was conducted to understand the effect these media have on production and nutritional quality of lettuce (Lactuca sativa L. cv. Catalogna Verde). Drought testing was carried out to understand how the media affected the lettuce's response to water stress. In comparison to perlite, yields under regular irrigation were reduced by $52 \%$ in almond shells and $72 \%$ in plastic planks, although lettuce grown in almond shells still obtained commercially relevant yields. Reduced yields in almond shells were likely caused by the shell's high salinity. Lettuce growth in plastic planks was limited by impeded root growth and low water-holding capacity. In conclusion, with minor alterations, almond shells could be used as a sustainable growing media alternative to perlite in hydroponic lettuce production. More research is needed to manufacture the planks to be conducive to plant growth.
\end{abstract}

Keywords: hydroponics; soilless culture; growing media; perlite; almond shells; drought; sustainable agriculture; circular economy; waste management

\section{Introduction}

\subsection{Hydroponics}

The interconnected challenges of climate change, extensive agricultural soil degradation, and dwindling freshwater resources, coupled with a rising urbanised population, threaten global food security [1-4]. Hydroponics, a system of crop cultivation without soil, offers an innovative solution for sustainable food production by preserving soil and land resources whilst reducing water usage in comparison to traditional agriculture [5-7]. Hydroponic systems are versatile and can range from passive, low-input systems to high-tech, fully automated systems, with system design easily adapted to local contexts [8-10]. Hydroponic systems can be implemented in areas that rely mainly on imported food products and are thus especially prone to food insecurity due to low availability of agricultural land or poor soil quality, such as deserts, dry coastal belts, and urban areas [11-13]. Hydroponics can increase food self-sufficiency in these communities, allow for local control of food resources, shorten the 
food supply chain, and decrease greenhouse gas emissions associated with food imports, thereby increasing resilience to climate change [13-16].

However, hydroponics also has economic and environmental disadvantages. Depending on the production system and level of automation, it can have high investment costs and require technical training, which could prevent its use by smallholders [5]. Commercial hydroponic enterprises can require extensive inputs of material infrastructure, synthetic nutrients, energy for lighting and pumps, and industrially processed growing media, while generating waste from plant residue, used growing media, and leachate $[14,17,18]$.

\subsection{Soilless Growing Media}

Soilless growing media are used in aggregate-based hydroponic systems, such as drip-irrigated or flood-and-drain systems [19]. The use of soilless growing media in hydroponic systems, compared to traditional soil-based agriculture, can improve crop yields because rates of water, nutrient, and oxygen transport are higher than in soil and can be easily optimised [20-22].

Soilless growing media can be classified based on the chemical makeup/origin (natural organic, synthetic organic, or inorganic) and the chemical activity/surface charge (active or semi-inert) [23]. Examples of commonly used natural organic media include peat, coconut coir, wood fibre, bark, sawdust, and composted plant waste [24]. Commonly used inorganic media include volcanic aluminosilicate materials (tuff, pumice, perlite, and zeolite), clay minerals (vermiculite and expanded clay), rockwool, and sand, while common synthetic organic media include polyurethane, urea-formaldehyde polymer foams, and polyester fleece [23].

The benefits of using natural organic media include natural sourcing, relatively lower purchasing costs in comparison to inorganic or engineered substrates, and additional nutrient provision to the crop $[23,25]$. However, organic materials can also prove problematic in soilless systems as they degrade over time (biological instability), leading to compaction and reduced aeration for plant roots [24,26]. Therefore, inorganic and synthetic media are often mixed with organic media in containerised culture, providing coarse particles that aid in aeration and water retention [27]. Inorganic and synthetic media can also be used on their own and are ideal in hydroponic systems since many are chemically inert, allowing for the nutrient solution to be easily adjusted to meet the exact needs of the plant [23].

Peat is the most widely used organic soilless media [24], while perlite and rockwool are the most commonly used inorganic media [28-30]. These are popular because of their ease of availability, low cost, and ideal physical and chemical characteristics [23,25,31,32]. However, the use of these media has drastic environmental implications. Peat is a nonrenewable resource which is being rapidly depleted [24]. Its extraction releases sequestered carbon, destroys natural habitats, and degrades the quality of groundwater in these areas $[33,34]$. Perlite and rockwool are both manufactured in energy-intensive processes at temperatures up to $1100^{\circ} \mathrm{C}$ and $1600^{\circ} \mathrm{C}$, respectively [23,35]. While perlite could potentially be reused for up to five years, reuse of substrates varies based on regional practices and grower expertise, and in many cases, both perlite and rockwool are used for only one to three crop cycles [29,36-39]. An additional consideration is that, upon disposal, perlite and rockwool are not biodegradable or easily recyclable.

\subsection{Novel, Sustainable Growing Media Alternatives}

Thus, there is a need to identify new environmentally and socially responsible soilless media based on local availability $[40,41]$. The adoption of new growing media will be contingent on the ability to produce rapid and uniform emergence during germination and consistent or improved crop yields compared to conventionally used media at lower or similar prices [41-43]. In addition, due to increasing issues of water scarcity worldwide, it is of interest to find media which could potentially reduce irrigation requirements in hydroponic systems [44]. Furthermore, with increased extreme weather events associated with climate change, it is desirable to investigate growing media which can 
provide buffering capacity in cases of water shortages to increase the resiliency of the hydroponic system to shocks that could occur during power outages [45].

A variety of novel, sustainable growing media have been identified from agricultural, industrial, and city waste products. This opens opportunities for alternative waste management and the generation of circular economies while also enabling the use of hydroponics by smallholders by drawing on local waste resources $[9,41,46]$. Repurposing these waste products as soilless growing media creates new products and markets within a circular economy and promotes the concept of cascading systems by using these wastes directly as feedstocks to drive further food production [47]. In particular, the use of agricultural waste products as soilless growing media allows for a regenerative process within the agricultural system, where the waste of traditional soil-based farms can feed directly into a sustainable soilless production system. This therefore maximises food production through the use of different growing methods for different spaces and land types. Examples of agricultural/food processing waste products that have been identified for use in soilless media include: almond shells [48-51], hazelnut husks [52-56], olive husks [42,57,58], grape marc [59], rice hulls [60-62], peanut hulls [63], biofuel or biomass crop residues [64], shredded maize stems [65,66], mezcal maguey bagasse [67], oil palm waste [68], sheep wool [69,70], and biochar produced from olive stone [71].

Almond shells in particular are a waste product which could provide a promising replacement for existing soilless culture [48-51]. Almonds are a low-input crop grown mainly in dry regions such as the Mediterranean, western United States, and Middle East, as they generally do not require irrigation and can grow in areas of poor soil quality [49,72]. These regions are well-suited for hydroponic production, as they are currently facing issues of freshwater scarcity and agricultural land degradation. In the Mediterranean region, especially in Spain, the use of perlite grow bags for hydroponic horticultural production is a common growing method $[30,39,73,74]$, although the use of perlite as a substrate is one of the main contributors to environmental impacts for these production systems [38]. Thus, using almond shells as a growing media presents an opportunity to repurpose a readily available local waste resource in these regions, contributing to the development of a circular economy [49].

In comparison to agricultural waste products from similar perennial culture industries (i.e., grape marc or olive husks), almond shells provide a more economically and environmentally viable option as they do not contain phytotoxic compounds and thus do not need extensive conditioning treatments before use [51,59]. Studies have shown that almond shells can be used for up to 530 days before having negative effects on fruit yield and quality in tomatoes and melons [75]. Thus, almond shells could be a competitive substrate replacement for perlite and rockwool, which are generally only used for one to two years $[28,75]$.

The engineering of durable substrates which can be reused over multiple crop cycles for hydroponic production has also gained attention recently [76-78]. Recycled plastic planks which are typically marketed as drainage materials show potential as a hydroponic substrate and for incorporation into green roofs $[79,80]$. These plastic materials can be reused continuously over many crop cycles using a simple cleaning process of submerging the planks in disinfectant. Thus, this provides a long-term, sustainable option for a hydroponic substrate that couples as an innovative waste management and circular economy solution by repurposing local recycled plastic from various municipal and industrial waste streams into a high value, long-life product.

This study aims to test the use of almond shells and recycled plastic drainage planks as sustainable growing media alternatives to perlite. Therefore, this assesses one alternative growing media option within the biosphere and one within the technosphere of a circular economy framework by investigating an organic material which can be composted at end-of-life and a synthetic material which can be reused over a long lifetime. Physical and chemical properties of the media were characterised, and the media were then evaluated on their performance in the germination and hydroponic production of lettuce (Lactuca sativa L. cv. Catalogna Verde). Hydroponic production in perlite grow bags was selected as the control system as it is a standard system for horticultural production in the Mediterranean region, and this system can be used in both commercial and small-scale urban growing contexts $[30,39,81]$. 
These media were also tested on their ability to mitigate stress in lettuce crops during an induced drought period, in order to understand their potential to reduce irrigation requirements and buffer shocks in the hydroponic system. This study thus identifies and evaluates two recycled material options which can be used in low-input hydroponic systems and further assesses their resiliency to stresses associated with climate change, such as water shortages.

\section{Materials and Methods}

\subsection{Growing Media Preparation}

Almond shells (AS) and a recycled plastic drainage plank (PDP) were compared to perlite (P) as the control in this study, to evaluate their performance as growing media for lettuce production. Sinclair standard horticultural grade perlite (2.0-5.0 mm) was used (Sinclair Pro; Ellesmere Port, UK). Almond shells were provided by Borges Andalucía (Almería, Spain) as a waste product from their almond processing operations. Raw almond shells were milled and blended, respectively, to two textures, fine $(<4 \mathrm{~mm})$ and coarse $(<4.75 \mathrm{~mm})$, and these were mixed in equal volumes for use as the growing media. The PDPs are composed of $100 \%$ mixed recycled thermoplastics, arranged in a dense network of polymer noodles with approximately $25 \%$ voids. This high strength plastic material has a unique surface tension which filters and directs the flow of water. Figure 1 provides zoomed images of the blended almond shells (Figure 1a), milled almond shells (Figure 1b), and the PDP (Figure 1c).

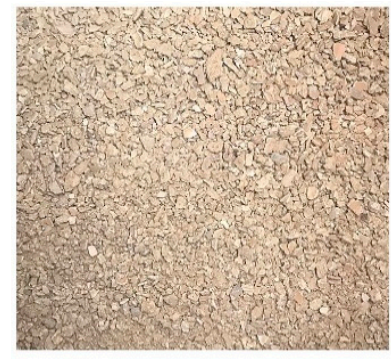

(a)

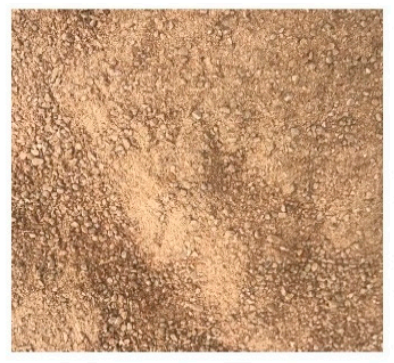

(b)

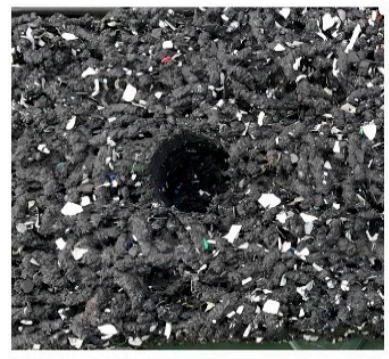

(c)

Figure 1. Zoomed images of the blended almond shells (a), milled almond shells (b), and the plastic drainage plank with a hole drilled inside for transplanting seedlings (c).

\subsection{Physical Properties of Growing Media}

Physical properties were assessed on a randomly mixed composite sample of each media. The following physical properties of growing media were evaluated: compacted bulk density [82]; dry bulk density [83]; effective pore space, defined as the volumetric amount of water which saturates the media [84-86]; particle size distribution via dry sieving [87]; coarseness index, defined as the percentage by mass of particles with sizes $>1 \mathrm{~mm}$ [88]; and dry matter and moisture content [89].

Water retention curves were measured for perlite and the almond shell media based on the method by Schindler and Müller [90] using the UMS Hyprop (METER Group; Munich, Germany). PDPs were not tested due to the poor contact between tensiometers and material. The following properties were obtained: water-holding capacity (water held in material at $1 \mathrm{kPa}$ suction), water buffering capacity (water loss in material between 5 and $10 \mathrm{kPa}$ suction), easily available water (water loss in material between 1 and $5 \mathrm{kPa}$ suction), and air-filled porosity (difference between the total porosity and water content at $1 \mathrm{kPa}$ suction) $[54,84,91]$.

Since water retention curves could not be generated for the PDPs, total water-holding capacity was calculated as the volume of water held in the planks after free drainage versus the material's dry volume [84]. The air-filled porosity was calculated as the volumetric percentage of the medium filled with air at the end of free gravitational drainage, which corresponds to the volume of water lost after drainage [86]. 
The saturated hydraulic conductivity $\left(\mathrm{K}_{\text {sat }}\right)$ was determined for perlite and almond shell samples by the constant head method [92] using a KSAT (METER Group; Munich, Germany). PDPs were tested, but due to extremely fast drainage, $\mathrm{K}_{\text {sat }}$ could not be determined accurately.

\subsection{Chemical Properties of Growing Media}

A representative, composite sample of the perlite and almond shell media were tested for chemical composition and organic matter content. These tests were not performed for PDPs due to lack of an appropriate testing method and equipment for plastic materials. Total $\mathrm{C}$ and $\mathrm{N}$ contents were determined by the Dumas technique [93]. Water-soluble nutrients were measured on a filtered extract using a weight equivalent to $60 \mathrm{~mL}$ of the sample and $300 \mathrm{~mL}$ of deionised water [82]. $\mathrm{Cl}, \mathrm{SO}_{4}-\mathrm{S}$, and $\mathrm{NO}_{3}-\mathrm{N}$ were determined via ion chromatography [94]. $\mathrm{NH}_{4}-\mathrm{N}$ was determined using colorimetric analysis [94]. P, K, Ca, Mg, Na, Fe, Mn, Cu, Zn, and B were determined using Inductively Coupled Plasma-Optical Emission Spectroscopy (ICP-OES) [89]. Organic matter content was determined as the loss of mass on ignition at $430^{\circ} \mathrm{C}[89,95]$. To measure $\mathrm{pH}$ and electrical conductivity (EC) of the growing media, an aqueous suspension was prepared in a 1:6 $(v / v)$ ratio of growing media to water, shaken at $250 \mathrm{rpm}$ for $1 \mathrm{~h}$. $\mathrm{pH}$ was then measured potentiometrically [96], and EC was measured using an EC meter $[97,98]$.

\subsection{Lettuce Germination Trial}

A germination study was carried out to evaluate the impact of the different growing media on the germination of Oakleaf lettuce (Lactuca sativa L. cv. Catalogna Verde) (Moles Seeds Ltd.; Colchester, UK). Seeds were germinated within individual cells in three germination trays, where each tray represented one experimental unit and held 10 randomly distributed cells of each growing media ( $\mathrm{P}, \mathrm{AS}$, and PDP). The 13-day germination study was conducted in a growth room at Newcastle University under semi-controlled environmental conditions with temperature ranging between 20 and $30{ }^{\circ} \mathrm{C}$ and daylength of $16 \mathrm{~h}$ in July 2018. Trait measurements consisted of germination percentage, time of emergence, seedling height, and number of leaves, measured according to the Cornell Hydroponic Lettuce Handbook [99].

\subsection{Lettuce Growth Trial}

\subsubsection{Experimental Design and Overview}

A greenhouse experiment was conducted to test the effect of different growing media and an induced drought period on the growth of Oakleaf lettuce (Lactuca sativa L. cv. Catalogna Verde). The study was conducted in a greenhouse at Newcastle University farms, and the experiment ran for 34 days (July-August 2018). Seedlings at the two-leaf stage, originally germinated in Humax Original compost (Humax; Ipswich, UK), were transplanted into each growing media. Temperatures during this experiment ranged from $12{ }^{\circ} \mathrm{C}$ at night to a maximum of $41{ }^{\circ} \mathrm{C}$ during the day (mean temperature $21.9^{\circ} \mathrm{C}$ ), with $91 \%$ of the days having temperatures that exceeded the optimal growing range for lettuce at $15-25^{\circ} \mathrm{C}$ [100]. Therefore, it should be noted that yields obtained during this trial could have been reduced due to unforeseen heat stress, which was experienced by lettuce growers across the UK [101].

Lettuce was grown in a hydroponic, drip-irrigated bag culture system, where each grow bag represented one experimental unit. A randomised complete block design was used with three growing media treatments (P, AS, PDP), two irrigation treatments (temporary induced drought [Dr] and regular irrigation [Reg]), three replications of each treatment, and three lettuce plants in each replication. Thus, a total of six treatments were evaluated (P Reg, AS Reg, PDP Reg, P Dr, AS Dr, and PDP Dr), with 9 lettuce plants grown per treatment at a planting density of 17 plants $\mathrm{m}^{-2}$. Grow bags of almond shells and perlite were approximately $50 \mathrm{~cm} \times 35 \mathrm{~cm} \times 15 \mathrm{~cm}$. Three stacked PDPs were also wrapped in bags of $50 \mathrm{~cm} \times 21 \mathrm{~cm} \times 9 \mathrm{~cm}$, with holes drilled into the top of the planks for transplanting lettuce seedlings. 


\subsubsection{Irrigation and Nutrient Solution}

Nonrecirculating drip irrigation $\left(0.9 \mathrm{~L} \mathrm{~h}^{-1}\right.$ flow rate) was used to control water and nutrient supply to the lettuce, with one drip emitter per plant. Perlite irrigation conditions were used as the baseline for all treatments. The irrigation schedule was formulated based on producing $30 \%$ leachate by volume in the perlite grow bags, which was equivalent to 7 events of $5 \mathrm{~min}$ per day. All seedlings were first irrigated for 14 days. After this period, irrigation was stopped in three replicates of each growing media to simulate a drought treatment. This lasted until the matric potential in the control growing media (perlite) reached $-20 \mathrm{kPa}(\sim 7$ days), followed by deployment of regular irrigation for all replicates for another week until harvest.

All crops were irrigated from the same $200 \mathrm{~L}$ reservoir containing nutrient solution made with potable water. This was prepared from stock solutions (Appendix A Table A1) based on formulations for leafy greens [102]. Each stock solution was added in equal proportions to the reservoir to maintain an EC that was 1.15-1.25 mS cm${ }^{-1}$ above potable water EC, which resulted in a final EC of 1.5-1.6 [99]. The $\mathrm{pH}$ of irrigation water was maintained between 5.6 and 6.0 [99]. Leachate from each grow bag was collected and tested periodically throughout the experiment for $\mathrm{pH}$ and $\mathrm{EC}$.

\subsubsection{Measurements}

During the induced drought period and thereafter until harvest, 30-min matric potential readings were taken using T5 tensiometers (METER Group; Munich, Germany). Stomatal conductance readings and infrared thermal images were taken on lettuce before, during, and after the drought period as indicators of stress, using a Porometer AP4 (Delta-T Devices Ltd.; Burwell, UK) and FLIR Thermal Camera (FLIR Systems, Inc.; West Malling, UK), respectively. Temperature readings from thermal images were normalised using a lettuce plant potted in compost as a temperature reference, which was incorporated in each picture during the imaging process [103].

At time of harvest, plant shoot fresh weight, root fresh weight, and number of leaves were determined. Errors in root weight measurements could have occurred as roots were broken in the media during extraction, especially for lettuce grown in PDPs. To obtain dry shoot and root weights, lettuce samples were freeze-dried for 7 days at $-20^{\circ} \mathrm{C}$ and then weighed.

Tissue analysis was also performed on homogenised samples of the lettuce leaves in triplicates for each treatment to obtain nutrient content. Samples were oven-dried and ground to pass through a $0.5 \mathrm{~mm}$ screen. $\mathrm{N}$ content was determined by the Dumas technique [93]. P, K, Mg, Ca, S, Mn, Zn, B, and $\mathrm{Cu}$ contents were determined by ICP-OES [89].

\subsection{Statistical Analysis}

All statistical analyses were carried out using the R commander package [104] in R [105]. Data were subjected to a two-way general linear model of analysis of variance (ANOVA) to determine treatment effects. Where significant effects were determined, Tukey's test was used to separate differences between treatment means at the $95 \%(p<0.05)$ level of confidence. For data sets with repeated-measures, a linear mixed-effects model was first applied using the nlme package in R [106], and a two-way, repeated-measures ANOVA was performed. Normality of residuals was tested with qqnorm and where necessary, data were cube root transformed.

\section{Results and Discussion}

\subsection{Physical and Chemical Properties of Growing Media}

Table 1 displays physical and chemical properties evaluated for the growing media used in this study compared to values considered ideal for soilless media. An additional chemical analysis was also performed for perlite and ground almond shells (Table A2). 
Table 1. Physical and chemical properties of growing media.

\begin{tabular}{|c|c|c|c|c|}
\hline Characteristic & Perlite & Almond Shells & Plastic Drainage Plank & Ideal Substrate \\
\hline \multicolumn{5}{|c|}{ Physical Properties } \\
\hline Compacted bulk density $\left(\mathrm{g} \mathrm{cm}^{-3}\right)$ & 0.106 & 0.78 & 0.47 & \\
\hline Dry bulk density $\left(\mathrm{g} \mathrm{cm}^{-3}\right)$ & 0.105 & 0.67 & 0.47 & $<0.40^{\mathrm{a}, \mathrm{b}}$ \\
\hline Oven dry matter (\%) & 99.3 & 87.5 & 99.9 & \\
\hline Moisture (\%) & 0.75 & 12.5 & 0.1 & \\
\hline Effective pore space (vol\%) & 56.8 & 60.4 & 30.5 & $\geq 85^{\mathrm{c}, \mathrm{d}}$ \\
\hline Air-filled porosity (vol\%) & 9.52 & 8.74 & 26.2 & $10-30$ a,b,e \\
\hline Total water-holding capacity $\left(\mathrm{mL} \mathrm{L}^{-1}\right)$ & 473 & 516 & 43.1 & $60-1000^{\mathrm{b}, \mathrm{e}}$ \\
\hline Easily available water $(\%)$ & 11.4 & 21.7 & $n / a$ & $2-30^{b, e}$ \\
\hline Water buffering capacity (\%) & 3.70 & 3.45 & $n / a$ & $4-10^{\mathrm{b}, \mathrm{e}}$ \\
\hline Saturated hydraulic conductivity $\left(\mathrm{m} \mathrm{s}^{-1}\right)$ & 0.073 & 0.00015 & $n / a$ & \\
\hline Coarseness Index $(\mathrm{wt} \%)$ & 78.9 & 59.1 & $n / a$ & \\
\hline \multicolumn{5}{|c|}{ Chemical Properties } \\
\hline $\mathrm{pH}$ & 6.9 & 5.2 & 9.3 & $5.2-6.3^{b}$ \\
\hline $\mathrm{EC}\left(\mathrm{mS} \mathrm{cm}^{-1}\right)$ & 0.007 & 0.574 & 0.401 & $\leq 0.5^{\mathrm{a}, \mathrm{e}-\mathrm{g}}$ \\
\hline Organic matter $(\%) *$ & 1 & 97.3 & $n / a$ & $>80^{b}$ \\
\hline C:N Ratio * & 0.32 & 48 & $n / a$ & $20-40^{e, g}$ \\
\hline
\end{tabular}

In general, perlite had suitable physical and chemical properties as expected, except for its generally low water-holding properties, due to its fast drainage. The main disadvantages of the almond shell media were its high bulk density, low air-filled porosity, and high EC, consistent with conclusions obtained by Valverde et al. [51]. The almond shells did have a higher water-holding capacity and easily available water than perlite, seen as a major advantage of this medium. This is in contrast to a previous study by Urrestarazu et al. [49], which reported low water-holding capacity and easily available water as the main problems of using almond shells as soilless media. Since the same source of almond shells (Borges Andalucía) was used in both studies, the differences likely arise from the fact that the almond shells were processed to a much finer particle size in this study (coarseness index of $59 \%$ compared to $85 \%$ ) which drastically increased the water-holding capacity by $169 \%$ and easily available water by $1708 \%$ compared to values found by Urrestarazu et al. [49]. However, the use of finer almond shell particles in this study also raised the bulk density and lowered the air-filled porosity outside the range of ideal values. Therefore, an ideal balance of fine and coarse particles must be found to improve the use of almond shells as a soilless growing media in the future. This could potentially be achieved by processing the almond shells solely from blending (rather than from a mix of blending and milling as in this study), which would give a coarseness index of $79 \%$ while still having nearly $50 \%$ of particles within the ideal range of $0.25-2.0 \mathrm{~mm}$ (Figure A1).

A major disadvantage of the PDP was its low effective pore space, which in both prior studies by the supplier and in this study was found to prevent root penetration and expansion. Additionally, since water can only be held in the PDPs via surface tension in the macropores created by the polymer noodles, this material has a very limited water-holding capacity. Thus, the PDPs could be improved as a hydroponic substrate by increasing total effective porosity, which could be adjusted during manufacturing. Additionally, creating a heterogenous pore size distribution within the media would likely improve its water-holding capacity, making this substrate more amenable to plant growth [85]. However, as the porosity of this material increases, it loses structural stability; thus, more research is needed to identify the ideal porosity needed in this medium to provide adequate conditions for plant growth.

Figure 2 displays the particle size distribution (a) and water retention curves (b) for perlite and ground almond shells. The $0.25-2.0 \mathrm{~mm}$ particle size range is considered as the ideal for growing media [107], as coarser materials will generally have excessive aeration and low water retention, and finer materials may prevent root penetration and decrease plant available water and aeration $[25,111,112]$. As seen in Figure $2 a$, the almond shell media used in this study had $74.6 \%$ of 
particles (by weight) within the range of $0.25-2.0 \mathrm{~mm}$, while perlite had only $36.2 \%$ of particles within this range. Further, the almond shell media had $17.4 \%$ of particles within the range of $0.1-0.5 \mathrm{~mm}$ compared to only $7.77 \%$ for perlite, which is the particle size range predicted to be responsible for easily available water and water-holding capacity in soilless media $[113,114]$.

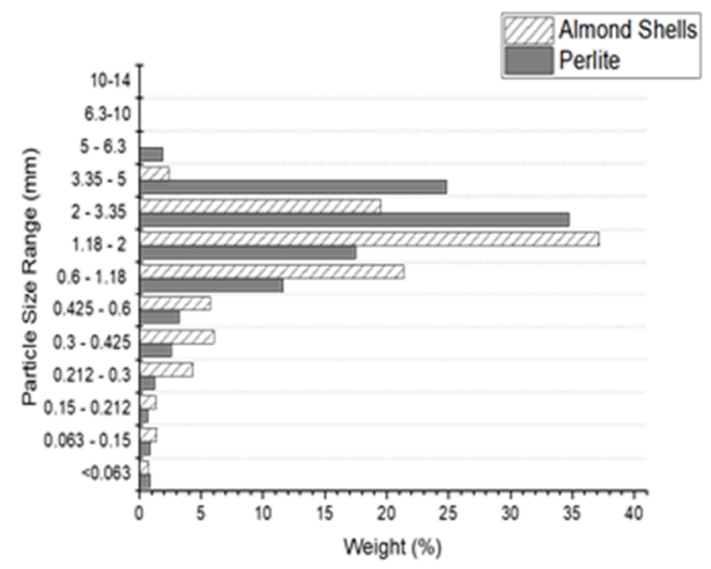

(a)

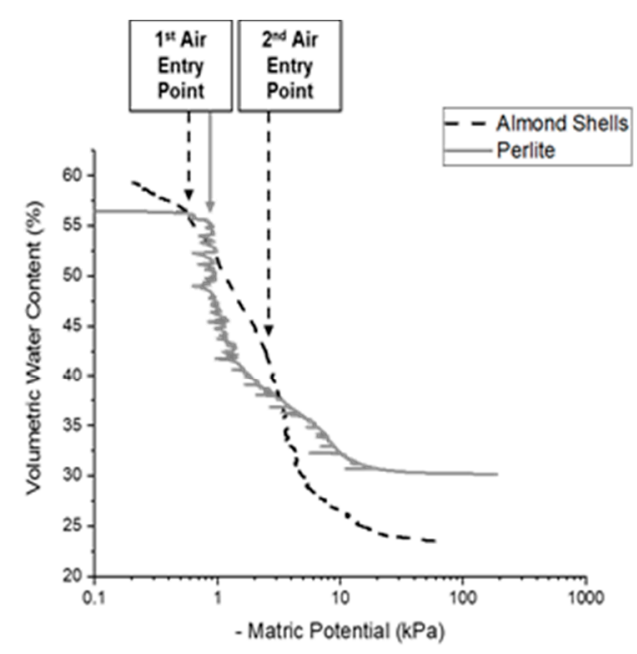

(b)

Figure 2. Particle size distribution (a) and water retention curves (b) of ground almond shells and perlite.

The almond shells also had a more heterogenous particle size distribution than perlite, owed to the different processing methods used (blending and milling), which created a heterogenous pore size distribution, allowing water to be held at various tensions in the media $[85,86]$. This is evidenced in Figure $2 b$, with the almond shell water retention curve exhibiting a low, gentle slope compared to perlite, as water drains slower from different pore sizes. Indeed, the drying of the saturated almond shells took 39 days compared to 13 days for perlite. In contrast, the rapid desaturation of perlite at $-0.9 \mathrm{kPa}$ indicates that this material has a more homogenous pore size distribution with a higher proportion of larger pores which drained quickly; this also contributes to higher air-filled porosity in comparison to the almond shells [115].

\subsection{Drought Stress}

During the drought period (25 July 2018-1 August 2018), three replicates of each growing media did not receive any irrigation, while three other replicates of each growing media remained under regular irrigation (seven irrigation events daily). From this period until harvest (7 August 2018), measures of stomatal conductance and leaf surface temperatures were taken as indicators of plant stress, with higher stress relating to lower stomatal conductance and higher leaf temperatures $[103,116]$. Growing media were evaluated on their ability to buffer drought stress by maintaining and holding water for the plant, therefore allowing the crop to maintain high stomatal conductance and productivity.

Figure 3 shows infrared thermal images taken of lettuce crops grown in each growing media and irrigation treatment throughout the drought period. The most obvious thermal stress is evidenced by the droughted lettuce grown in the PDPs, where increased leaf surface temperatures can be observed just after the first missed irrigation. This is expected as the PDPs have very minimal water-holding capacity. Little difference is seen between regularly irrigated and droughted lettuce grown in perlite and almond shells. In some cases, stress seems to lessen in droughted crops over time, although this can be attributed to variability in daytime temperature. Still, thermal imaging can be used as a quick way to evaluate crop stress; however, to evaluate significant differences it is necessary to compare measured values of stomatal conductance and leaf surface temperatures (Figures A2 and A3). 


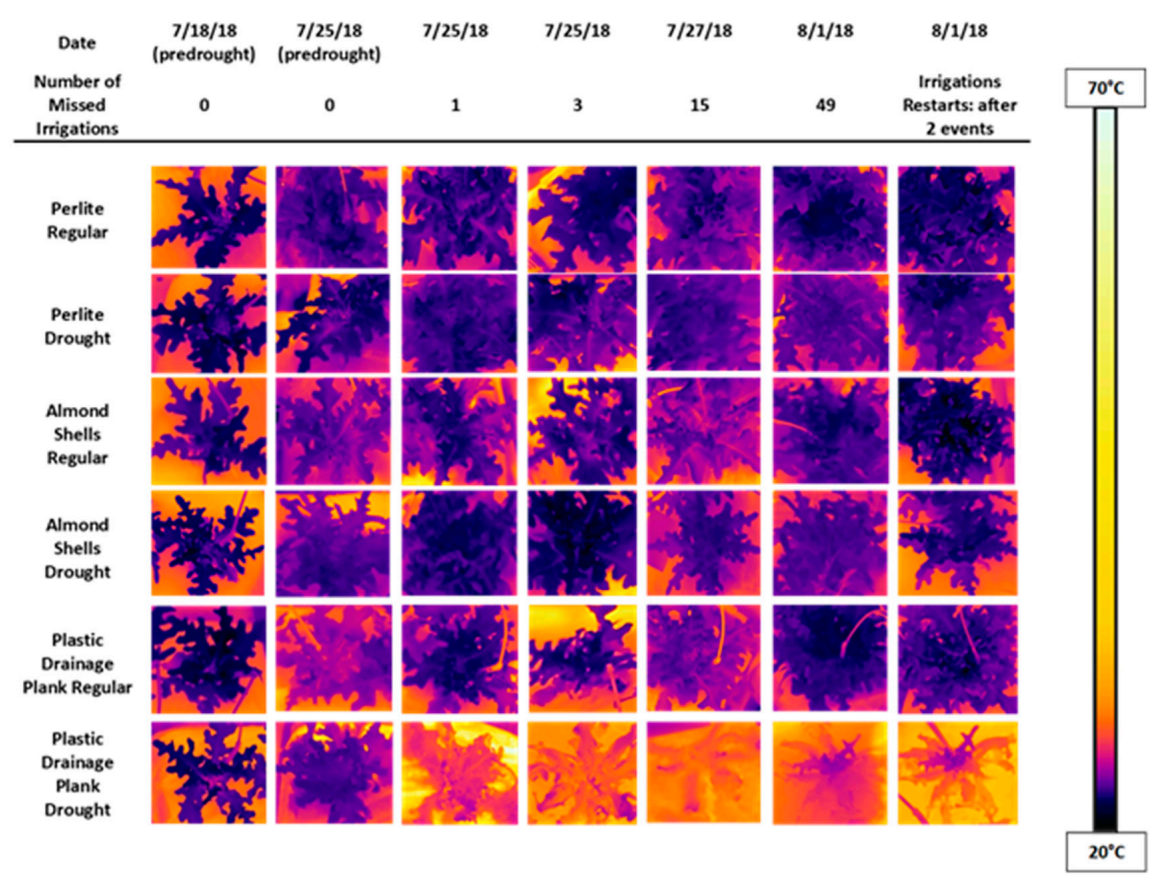

Figure 3. Thermal images of lettuce grown in regularly irrigated and droughted media.

Table 2 displays values of stomatal conductance and normalised leaf surface temperatures averaged across media and irrigation treatments from several readings taken throughout the drought period. It is important to note that these measurements are highly dependent on other environmental conditions, such as varying air/media temperature, wind speed, humidity, irradiance, and complexities of the canopy structure (i.e., leaf angles and layering) [117]; in order to compensate for that, a normalisation technique was utilised as described in Prashar and Jones [103,118].

Growing media, irrigation, and time all significantly affected stomatal conductance and leaf surface temperatures $(p<0.001)$. Average values of stomatal conductance were lower for droughted lettuce compared to regularly irrigated lettuce grown in the same media $(p<0.05)$, thus demonstrating that lettuce undergoing drought in each media experienced signs of stress. However, the significant interaction between growing media and irrigation treatment for both stomatal conductance and leaf surface temperatures $(p<0.01)$ demonstrates that the induced drought affected the lettuce grown in each media differently. Droughted lettuce grown in perlite had significantly higher stomatal conductance than those grown in PDPs $(p<0.001)$, with those grown in almond shells not being significantly different from either $(p>0.05)$. The only significant difference in normalised leaf surface temperatures averaged over the drought period was for droughted lettuce grown in PDPs, which showed higher values compared to all other treatments $(p<0.001)$. There were no significant differences in stomatal conductance or leaf surface temperatures between regularly irrigated crops over the drought period $(p>0.1)$.

Figures A2 and A3 show the individual readings of stomatal conductance and leaf surface temperature measurements taken on different days. Results show that after the first missed irrigation, droughted lettuce growing in the PDPs already showed lower stomatal conductance $(p<0.1)$ and higher leaf surface temperatures $(p>0.05)$ than the regularly irrigated lettuce. By the third missed irrigation, droughted lettuce grown in almond shells showed a lower stomatal conductance than the regularly irrigated lettuce grown in perlite and almond shells $(p<0.05)$, and by the 15th missed irrigation, droughted lettuce grown in perlite also had a lower stomatal conductance than regularly irrigated lettuce grown in the same media $(p<0.001)$. Leaf surface temperatures of lettuce grown in both perlite and almond shells did not significantly differ from regularly irrigated crops throughout the drought period. 
Table 2. Stomatal conductance and normalised leaf surface temperatures during the drought period.

\begin{tabular}{|c|c|c|}
\hline & $\begin{array}{l}\text { Stomatal Conductance (mmol } \\
\left.\qquad \mathrm{m}^{-2} \mathrm{~s}^{-1}\right)^{a}\end{array}$ & $\begin{array}{l}\text { Normalised Leaf Surface } \\
\text { Temperature }\left({ }^{\circ} \mathrm{C}\right)^{b}\end{array}$ \\
\hline \multicolumn{3}{|l|}{$\begin{array}{l}\text { Main effect means } \\
\text { Irrigation }\end{array}$} \\
\hline $\operatorname{Reg}$ & $734 \pm 76.4 \mathrm{a}$ & $-1.91 \pm 0.48 \mathrm{a}$ \\
\hline Dr & $239 \pm 37.1 b$ & $1.15 \pm 0.83 \mathrm{~b}$ \\
\hline \multicolumn{3}{|l|}{ Growing Media } \\
\hline $\mathbf{P}$ & $663 \pm 98 \mathrm{a}$ & $-2.67 \pm 0.49 a$ \\
\hline AS PDP & $\begin{array}{l}492 \pm 80.3 a, b \\
304 \pm 67.5 b\end{array}$ & $\begin{array}{c}-1.63 \pm 0.51 \mathrm{a} \\
3.14 \pm 1.04 \mathrm{~b}\end{array}$ \\
\hline \multicolumn{3}{|l|}{ Interaction means } \\
\hline P Reg & $872 \pm 165 \mathrm{a}$ & $-3.13 \pm 0.58 a$ \\
\hline P Dr & $455 \pm 78.2 \mathrm{~b}, \mathrm{c}$ & $-2.20 \pm 0.78 a$ \\
\hline AS Reg & $791 \pm 114 \mathrm{a}, \mathrm{b}$ & $-2.19 \pm 0.39 a$ \\
\hline AS Dr & $193 \pm 32.4 \mathrm{c}, \mathrm{d}$ & $-1.06 \pm 0.93 a$ \\
\hline PDP Reg & $538 \pm 104 a, b$ & $-0.42 \pm 1.15 a$ \\
\hline PDP Dr & $69.5 \pm 16.8 \mathrm{~d}$ & $6.70 \pm 0.94 b$ \\
\hline \multicolumn{3}{|l|}{ ANOVA $p$-values } \\
\hline Substrate & $<0.0001$ & $<0.0001$ \\
\hline Irrigation & $<0.0001$ & 0.0009 \\
\hline Time & $<0.0001$ & $<0.0001$ \\
\hline Substrate $\times$ Irrigation & 0.0029 & 0.0073 \\
\hline Substrate $\times$ Time & 0.0011 & 0.0654 \\
\hline Irrigation $\times$ Time & $<0.0001$ & 0.2234 \\
\hline Substrate $\times$ Irrigation $\times$ Time & 0.0034 & 0.5960 \\
\hline
\end{tabular}

Values are mean \pm standard error $(n=9$ for irrigation main effect means; $n=6$ for substrate main effect means; $n=3$ for interaction means). Means followed by a different letter in the same column indicate significant differences by Tukey's test at a significance level $p<0.05$. ANOVA $p$-values were generated from cube root transformed data, with boldface used for significance $(p<0.05)$. ${ }^{\text {a }}$ Means are averaged from readings taken at time points relating to the following numbers of missed irrigation events: 1, 3, 8, 15, 49. Drought lasted for 7 days with 7 irrigation events per day. ${ }^{b}$ Means are averaged from readings taken at time points relating to the following numbers of missed irrigation events: $1,3,15,49$.

Lettuce grown in perlite showed the lowest signs of stress, maintaining the highest stomatal conductance and lowest leaf surface temperatures throughout the drought period compared to other media, although values for lettuce grown in almond shells were not significantly different when averaged over the entire drought period (Table 2). Almond shells were able to provide some buffering capacity to drought but did not reduce stress in the lettuce as much as expected based on high water retention characteristics, which were also evidenced through tensiometer readings taken throughout the drought period, showing that almond shells retained moisture at the lowest suction potential throughout the drought (Figure A4). The enhanced stress seen in the lettuce grown in almond shells compared to perlite under drought may have been due to exaggerated osmotic stress from the combined effects of the drought and the high salinity of the almond shell media, which would not have been reflected in tensiometer readings of matric (not osmotic) potential [86].

Lettuce grown in the PDPs were extremely responsive to drought due to its almost negligible water-holding capacity. The effects of drought stress were likely compounded by the high heat retention of the material. Thermal conductivities of thermoplastics are an order of magnitude higher than for common horticultural substrates, such as perlite, clay, peat, and bark, so the PDPs are more receptive to ambient temperature changes $[119,120]$. These results show that PDPs cannot provide any buffering capacity to decrease plant stress in times of drought and should therefore only be used in hydroponic systems that utilise a constant supply of water, such as deep water culture, floating raft systems, and nutrient film technique [10].

\subsection{Germination}

Table 3 displays results from the germination trial. While there was no significant difference in final germination percentage between media $(p>0.05)$, seedlings grown in perlite had a higher final 
height and number of real leaves than those grown in the PDPs, which were higher than those grown in almond shells $(p<0.001)$. A faster emergence time was observed when germinated in perlite compared to PDPs $(p<0.05)$, with the emergence time for seeds sown in almond shells not being significantly different from the other media $(p>0.05)$. This demonstrates that seeds could germinate effectively in PDPs, which would improve the material's use in plant production as transplanting seedlings into its dense structure would not be necessary.

Table 3. Growth parameters from germination study.

\begin{tabular}{ccccc}
\hline Growing Media & $\begin{array}{c}\text { Final\% } \\
\text { Germination }\end{array}$ & $\begin{array}{c}\text { Average Emergence } \\
\text { Time (Days) }\end{array}$ & $\begin{array}{c}\text { Final Seedling } \\
\text { Height }(\mathrm{cm})\end{array}$ & $\begin{array}{c}\text { Final Number of } \\
\text { Real Leaves }\end{array}$ \\
\hline P & $96.7 \pm 3.33 \mathrm{a}$ & $2.24 \pm 0.04 \mathrm{a}$ & $7.77 \pm 0.11 \mathrm{a}$ & $2.93 \pm 0.13 \mathrm{a}$ \\
AS & $96.7 \pm 3.33 \mathrm{a}$ & $2.52 \pm 0.13 \mathrm{a}, \mathrm{b}$ & $1.71 \pm 0.12 \mathrm{c}$ & $0.76 \pm 0.09 \mathrm{c}$ \\
PDP & $76.7 \pm 8.82 \mathrm{a}$ & $2.69 \pm 0.08 \mathrm{~b}$ & $5.91 \pm 0.40 \mathrm{~b}$ & $2.00 \pm 0.23 \mathrm{~b}$ \\
\hline
\end{tabular}

Values are mean \pm standard error $(n=3)$. Means followed by a different letter in the same column indicate significant differences by Tukey's test at a significance level $p<0.05$.

\subsection{Yields}

Table 4 provides an overview of lettuce yield characteristics at the time of harvest based on growing media and irrigation treatments. Lettuce grown in perlite had a higher average fresh and dry shoot weight than lettuce grown in almond shells, followed by lettuce grown in PDPs $(p<0.001)$. Root fresh and dry weight were higher in lettuce grown in almond shells than in perlite, which had a higher root fresh and dry weight than lettuce grown in PDPs $(p<0.001)$. The number of leaves per plant was not significantly different for lettuce grown in perlite and almond shells, but was higher in these media than in PDPs $(p<0.05)$. Thus, the higher shoot weights for lettuce grown in perlite compared to almond shells can be attributed to either larger leaf areas or thicker leaves rather than the number of leaves. The induced drought period lowered fresh shoot weights for all treatments when compared to regularly irrigated lettuce grown in the same media $(p<0.01)$.

Table 4. Total yields of lettuce grown in perlite, almond shells, and plastic drainage planks under regular irrigation and drought.

\begin{tabular}{|c|c|c|c|c|c|}
\hline Substrate & $\begin{array}{c}\text { Shoot Fresh } \\
\text { Weight }\left(\mathrm{g}_{\text {plant }}{ }^{-1}\right)\end{array}$ & $\begin{array}{l}\text { Shoot Dry Weight } \\
\left(\mathrm{g}_{\text {plant }}{ }^{-1}\right)\end{array}$ & $\begin{array}{l}\text { Root Fresh Weight } \\
\quad\left(\mathrm{g} \mathrm{plant}^{-1}\right)\end{array}$ & $\begin{array}{l}\text { Root Dry Weight } \\
\left(\mathrm{g} \text { plant }{ }^{-1}\right)\end{array}$ & $\begin{array}{c}\text { Number of Leaves } \\
\text { per Plant }\end{array}$ \\
\hline P Reg & $280 \pm 56.1 \mathrm{a}$ & $15.8 \pm 2.30 \mathrm{a}$ & $9.98 \pm 18.7 b$ & $0.76 \pm 0.77 c$ & $28.0 \pm 0.67 \mathrm{a}$ \\
\hline AS Reg & $134 \pm 43.3 \mathrm{c}, \mathrm{d}$ & $9.42 \pm 8.31 b, c$ & $29.1 \pm 14.4 \mathrm{a}$ & $4.74 \pm 2.77 b$ & $29.0 \pm 1.26 \mathrm{a}$ \\
\hline PDP Reg & $78.4 \pm 28.4 \mathrm{~d}, \mathrm{e}$ & $6.21 \pm 3.23 \mathrm{c}, \mathrm{d}$ & $8.27 \pm 9.48 b$ & $1.33 \pm 0.82 c$ & $24.3 \pm 1.39 a$ \\
\hline P Dr & $166 \pm 26.1 b, c$ & $12.2 \pm 3.82 \mathrm{a}, \mathrm{b}$ & $11.1 \pm 8.69 \mathrm{~b}$ & $1.11 \pm 1.27 \mathrm{c}$ & $28.9 \pm 0.48 \mathrm{a}$ \\
\hline AS Dr & $63.5 \pm 52.5 \mathrm{e}, \mathrm{f}$ & $7.92 \pm 7.47 b, c$ & $31.8 \pm 17.5 \mathrm{a}$ & $6.84 \pm 2.49 \mathrm{a}$ & $23.9 \pm 2.56 \mathrm{a}$ \\
\hline PDP Dr & $14.2 \pm 7.46 \mathrm{f}$ & $1.24 \pm 2.25 \mathrm{~d}$ & $3.37 \pm 5.37 b$ & $0.33 \pm 0.89 c$ & $11.6 \pm 3.20 \mathrm{~b}$ \\
\hline
\end{tabular}

Values are mean \pm standard error $(n=3)$. Means followed by a different letter in the same column indicate significant differences by Tukey's test at a significance level $p<0.05$.

\subsubsection{Effect of Growing Media on Yields}

Shoot fresh and dry weights of lettuce crops grown in regularly irrigated perlite and almond shells, as well as perlite under drought, were consistent with hydroponic lettuce yields reported in the literature, which range from 160 to $268 \mathrm{~g} \mathrm{plant}^{-1}$ for fresh weight and 6.4 to $13.3 \mathrm{~g} \mathrm{plant}^{-1}$ for dry weight, depending on system type and lettuce variety [121-124]. This therefore indicates production relevant to commercial standards for lettuce crops grown in these treatments, showing that almond shells could still be used as an environmentally conscious media replacement, even though fresh weight yields were $52 \%$ lower than in perlite. Lettuce grown in PDPs were not able to reach a commercially relevant yield.

A possible reason for the lower yields of lettuce grown in almond shells compared to perlite is the high salinity of the almond shell media. Indeed, Chong [125] identified high salt content as one of the 
main limitations of using organic-derived wastes as growing media alternatives. A study by Andriolo et al. [121] showed that lettuce exposure to salinity levels above $2.0 \mathrm{mS} \mathrm{cm}^{-1}$ in nutrient film technique hydroponic systems led to reductions in fresh shoot weight, with salinity levels adjusted via applied nutrient concentrations. In this experiment, the nutrient solution was kept within an optimal range of $1.5-1.6 \mathrm{mS} \mathrm{cm}^{-1}$, and the salinity of the almond shell media was measured as $0.574 \mathrm{mS} \mathrm{cm}^{-1}$; this could have therefore brought the salinity level above the $2.0 \mathrm{mS} \mathrm{cm}^{-1}$ threshold. The EC of leachate from the almond shell media during the first week of growth was found to be exceptionally high, at an average of $4.07 \mathrm{mS} \mathrm{cm}^{-1}$, compared with perlite and PDPs at 1.06 and $1.30 \mathrm{mS} \mathrm{cm}^{-1}$, respectively. High salinity levels cause decreases in leaf expansion and total leaf area, thus limiting plant growth and lowering final yields [126-129]. Since the EC of the almond shell leachate lowered by the end of the growth trial (at an average EC of $1.2 \mathrm{mS} \mathrm{cm}^{-1}$ by the third week), and lettuce grown in almond shells and perlite did not significantly differ in the number of leaves, it is possible that the initial exposure of the lettuce to high saline levels in the almond shells after transplantation caused reduced leaf areas, thereby preventing future growth by lowering water and mineral uptake and rates of photosynthesis. Thus, in accordance with recommendations by Chong [125] for organic waste materials with a high initial soluble salt content, it is possible that yields of lettuce grown in almond shells could be increased if the media is washed or leached by running one or several irrigation cycles to lower its EC prior to use.

Additional causes of the lower yields in the almond shells could be low air-filled porosity, high water retention capacity, and slow desaturation rate, which combined could have led to waterlogging with regular irrigation over time, reducing oxygen supply to plant roots $[26,130,131]$. This could be amended by changing the irrigation schedule or by adjusting the particle size distribution of the media to be coarser, encouraging aeration and drainage. Finally, as the fresh and dry root weight was significantly higher in lettuce plants grown in almond shells compared to perlite, this indicates that plants grown in the almond shells may have been experiencing nutrient deficiencies. Indeed, the high C:N ratio (48) of the almond shell media in comparison to ideal levels for soilless media (20-40) could have led to $\mathrm{N}$ immobilisation in the substrate $[91,110,132]$, and $\mathrm{N}$ deficiencies have been shown to lead to decreases in shoot/root ratios in plants as $\mathrm{N}$ and biomass becomes allocated to the roots $[133,134]$. However, the degree to which this influenced yields is not certain. A study from Broadley et al. [134] showed that stomatal conductance, an indicator of plant stress and C assimilation, was significantly lower in N-limited lettuce plants than in control plants; however, in this study, while the stomatal conductance for lettuce grown in almond shells was lower compared those grown in perlite, it was not significantly different.

For lettuce grown in PDPs, a likely cause for lower yields could be restricted root growth, as it was observed that roots formed a confined ball between the first and second stacked planks. Indeed, roots penetrated only through the first plank in which the seedlings were set. Poor root growth, caused by high mechanical impedance of the substrate, has been identified as a major factor contributing to reduced vegetative growth for plants grown in both soils and soilless media [135-137]. The low water-holding capacity of the material was also a likely cause of reduced plant growth, as plant roots were only able to take up water during irrigation events, with excess water being immediately leached from the material. This issue was compounded by the low and confined root growth, which further reduced the surface area available for water uptake [132].

Yields for lettuce grown in PDPs would likely be improved if manufactured with increased porosity and a more variable pore size distribution, which would allow for better root development and potentially increase water retention capabilities. PDPs would be better used as a hydroponic substrate in hydroponic systems featuring continuous water supply. In general, it was shown that plants could grow in the material, so PDPs could be used in green roofs even if not specifically for crop production $[79,80]$. Since germination was effective in PDPs (Table 3), it would be easy to continuously seed and grow in this medium. This would allow recycled plastic planks to be incorporated as a long-life material for sustainable building design, providing dual purposes of drainage as well as a medium for plant growth. 


\subsubsection{Effect of Drought on Yields}

Overall, the effect of drought decreased fresh shoot yields of lettuce grown in perlite, almond shells, and PDPs by $41 \%, 53 \%$, and $82 \%$, respectively, compared to yields of regularly irrigated lettuce in the same media. Reductions in shoot dry weights were less profound, with reductions of $22.7 \%, 15.9 \%$, and $80 \%$ for droughted lettuce grown in perlite, almond shells, and PDPs, respectively. For perlite and almond shells, this is consistent with the $25 \%$ reduction in shoot dry weight seen in a study by Kerbiriou et al. [138], where two cultivars of butterhead lettuce potted in soil and river sand were placed under a drought period 21 days after transplanting and then allowed a recovery period of one week, which was similar to the timeline of drought in this study. Only lettuce crops grown in perlite were able to produce commercially relevant yields after drought. This indicates that commercial systems which utilise perlite as a growing media could potentially reduce irrigation frequency, conserving water, and still produce commercially relevant yields.

Since the almond shell media was able to maintain the lowest water tension over the drought period (Figure A4), this could allow for improved water use efficiency in plants if other stresses, such as salt stress from the media, were removed and overall yields were increased [139].

\subsection{Nutritional Quality}

Micronutrient deficiencies are a major problem in both the developed and developing world, and these issues are expected to increase with declining soil fertility, increased drought, and high $\mathrm{CO}_{2}$ levels associated with climate change [140-143]. Thus, there is a demand for vegetables of high nutritional quality, and, therefore, a need to identify media which can appropriately transfer nutrients to plant roots, especially in cases of water- or nutrient-limited conditions [22,26,144,145].

Table 5 displays mean nutrient concentrations of lettuce tissue evaluated after harvest for each treatment individually, as well as optimal nutrient concentrations for lettuce defined by literature. Lettuce grown in almond shells showed $\mathrm{N}, \mathrm{Mg}$, and Fe deficiencies, while lettuce grown in perlite showed $\mathrm{Mg}, \mathrm{Fe}$, and B deficiencies. Lettuce grown in PDPs showed no signs of nutrient deficiencies. In addition, all treatments except for perlite under drought showed excess levels of $\mathrm{Zn}$ in the leaf tissue; however, these values of high $\mathrm{Zn}$ were consistent with ranges of $\mathrm{Zn}\left(105-238 \mathrm{mg} \mathrm{kg}^{-1}\right)$ found for 18 different cultivars of lettuce grown hydroponically in both inorganic and organic nutrient solutions [146]. 
Table 5. Nutrient concentrations of lettuce (dry weight) grown in perlite, almond shells, and plastic drainage planks under regular irrigation and drought.

\begin{tabular}{|c|c|c|c|c|c|c|c|}
\hline Element & P Reg & AS Reg & PDP Reg & P Dr & AS Dr & PDP Dr & Optimum Levels \\
\hline$N\left(g_{k g}^{-1}\right)$ & $36.2 \pm 1.0 \mathrm{a}$ & $26.6 \pm 1.88 c$ & $30.8 \pm 1.05 b, c$ & $29.5 \pm 0.95 c$ & $17.8 \pm 0.19 \mathrm{~d}$ & $35.7 \pm 0.35 \mathrm{a}, \mathrm{b}$ & $30-55^{a-d}$ \\
\hline$P\left(g_{k g}^{-1}\right)$ & $7.36 \pm 0.07 \mathrm{a}$ & $5.93 \pm 0.39 b$ & $6.24 \pm 0.19 a, b$ & $6.07 \pm 0.39 b$ & $3.90 \pm 0.12 c$ & $6.35 \pm 0.15 a, b$ & $3.5-7.7^{\mathrm{c}, \mathrm{d}}$ \\
\hline $\mathrm{K}\left(\mathrm{g} \mathrm{kg}^{-1}\right)$ & $71.7 \pm 3.36 \mathrm{a}$ & $65.9 \pm 1.98 \mathrm{a}$ & $70.9 \pm 2.73 \mathrm{a}$ & $63.9 \pm 3.92 \mathrm{a}$ & $49.2 \pm 2.10 \mathrm{~b}$ & $72.7 \pm 1.49 \mathrm{a}$ & $42-100^{a-c}$ \\
\hline $\mathrm{Ca}\left(\mathrm{g} \mathrm{kg}^{-1}\right)$ & $11.4 \pm 0.54 b$ & $14.7 \pm 0.66 \mathrm{a}$ & $14.8 \pm 1.01 \mathrm{a}$ & $13.5 \pm 0.33 \mathrm{a}, \mathrm{b}$ & $13.3 \pm 0.26 \mathrm{a}, \mathrm{b}$ & $13.1 \pm 0.31 \mathrm{a}, \mathrm{b}$ & $9-25^{a-c}$ \\
\hline $\operatorname{Mg}\left(\mathrm{g} \mathrm{kg}^{-1}\right)$ & $1.97 \pm 0.07 b$ & $1.97 \pm 0.14 b$ & $2.68 \pm 0.15 a$ & $2.42 \pm 0.12 \mathrm{a}, \mathrm{b}$ & $2.33 \pm 0.12 a, b$ & $2.67 \pm 0.02 \mathrm{a}$ & $2.5-6^{\mathrm{b}, \mathrm{c}, \mathrm{d}}$ \\
\hline $\mathrm{S}\left(\mathrm{g} \mathrm{kg}^{-1}\right)$ & $2.72 \pm 0.02 b$ & $1.98 \pm 0.10 \mathrm{~d}$ & $2.67 \pm 0.07 b$ & $2.33 \pm 0.10 c$ & $1.66 \pm 0.05 \mathrm{~d}$ & $3.36 \pm 0.05 \mathrm{a}$ & $1.5^{-3.5^{b, c, d}}$ \\
\hline $\mathrm{Fe}\left(\mathrm{mg} \mathrm{kg}{ }^{-1}\right)$ & $95.2 \pm 1.84 b, c$ & $75.5 \pm 6.54 c$ & $156 \pm 12.5 \mathrm{a}$ & $110 \pm 12.4 a, b$ & $105 \pm 5.51 b, c$ & $130 \pm 7.17 \mathrm{a}, \mathrm{b}$ & $115-257^{\mathrm{d}}$ \\
\hline $\operatorname{Mn}\left(\mathrm{mg} \mathrm{kg}^{-1}\right)$ & $56.4 \pm 2.84 \mathrm{~b}, \mathrm{c}$ & $76.3 \pm 1.36 \mathrm{a}$ & $69.6 \pm 6.64 \mathrm{a}, \mathrm{b}$ & $49.5 \pm 0.98 c$ & $65.7 \pm 3.82 a, b, c$ & $73.2 \pm 0.78 \mathrm{a}$ & $30-100 \mathrm{c,d}$ \\
\hline $\mathrm{Cu}\left(\mathrm{mg} \mathrm{kg}^{-1}\right)$ & $7.84 \pm 0.25 a$ & $6.14 \pm 0.71 \mathrm{a}$ & $7.29 \pm 0.40 \mathrm{a}$ & $6.22 \pm 0.36 \mathrm{a}$ & $3.34 \pm 0.26 \mathrm{~b}$ & $6.58 \pm 0.21 \mathrm{a}$ & $5-20^{c, d}$ \\
\hline $\mathrm{Zn}\left(\mathrm{mg} \mathrm{kg} \mathrm{kg}^{-1}\right)$ & $115 \pm 4.98 b, c$ & $194 \pm 21.9 a$ & $162 \pm 16.1 \mathrm{a}, \mathrm{b}$ & $97.4 \pm 10.3 c$ & $\mathbf{1 1 4} \pm 8.19 \mathrm{~b}, \mathrm{c}$ & $152 \pm 1.20 a, b, c$ & $25-100 \mathrm{c}, \mathrm{d}$ \\
\hline$B\left(\mathrm{mg} \mathrm{kg}^{-1}\right)$ & $19.8 \pm 0.42 c$ & $29.1 \pm 0.92 \mathrm{a}$ & $24.8 \pm 1.03 \mathrm{~b}$ & $18.5 \pm 0.40 c$ & $29.1 \pm 0.38 \mathrm{a}$ & $26.9 \pm 0.50 \mathrm{a}, \mathrm{b}$ & $24-36^{\mathrm{d}}$ \\
\hline
\end{tabular}

Values are mean \pm standard error $(n=3)$. Means followed by a different letter in the same column indicate significant differences by Tukey's test at a significance level $p<0.05$. Boldface is used to indicate means lying outside the optimal values. ${ }^{\mathrm{a}}$ [147]; ${ }^{\mathrm{b}}$ [148]; ${ }^{\mathrm{c}}$ [149]; ${ }^{\mathrm{d}}$ [150]. 


\subsubsection{Effect of Growing Media on Nutritional Quality}

Despite massive reductions in yields, lettuce grown in PDPs consistently had the highest (or not significantly different from the highest) concentrations of all mineral nutrients. This can possibly be explained by the confined root ball structure which formed in between the planks in the grow bag. In times of irrigation, the nutrient solution was applied from the drip stakes directly onto the root ball, which may have allowed for immediate nutrient uptake, compared to the solution being absorbed by the media and then gradually diffusing to the roots such as in perlite and almond shells.

Lettuce grown in almond shells had significantly higher levels of micronutrients, including Mn, $\mathrm{Zn}$, and $\mathrm{B}$, compared to lettuce grown in perlite. This could be due to the higher presence of these minerals in the substrate itself (Table A2), as well as the low $\mathrm{pH}$ (5.2) of the almond shell media, as these micronutrients are all preferentially absorbed at $\mathrm{pH}$ values below 6.0 [151]. However, lettuce crops grown in PDPs did not have significantly different concentrations of $\mathrm{Mn}$ and $\mathrm{Zn}$ than those grown in almond shells, despite the high $\mathrm{pH}$ of this media. Still, it is possible that the $\mathrm{pH}$ of the PDPs did not affect nutrient uptake in lettuce crops, since the nutrient solution had little contact with the substrate before falling directly on the root ball of crops during irrigation, and little nutrient solution was held in the material after irrigation events. Additionally, a study by Neocleous et al. [152] showed that higher salinity levels generally increased the concentrations of $\mathrm{Mn}, \mathrm{Zn}$, and B in baby lettuce leaves; this could have further influenced the higher concentrations of these nutrients present in lettuce grown in almond shells due to the relatively high EC of this growing media.

The lower levels of macronutrients such as $\mathrm{N}, \mathrm{P}, \mathrm{K}, \mathrm{Mg}$, and $\mathrm{S}$ found in lettuce crops grown in almond shells versus either perlite or PDPs could also be due to the low $\mathrm{pH}$ of the almond shells (5.2), as these nutrients are preferentially absorbed at higher $\mathrm{pH}$ levels between 6.5 and 8.0 [151]. This issue may have been further exaggerated throughout the crop cycle, as a previous study by Valverde et al. [51] observed a 0.5 decrease in the $\mathrm{pH}$ of almond shells during the growth of sweet peppers, likely caused by the production of organic acids from degrading carbon in the media, which occurs during aerobic composting [153]. The fact that the $\mathrm{N}$ content of lettuce grown in almond shells was below optimal levels and was significantly lower than $\mathrm{N}$ levels for crops grown in perlite indicates that decreased $\mathrm{N}$ uptake could have been a limiting factor in lettuce growth, likely caused by $\mathrm{N}$ immobilisation in the substrate because of the high C concentration [91,110,132].

\subsubsection{Effect of Drought on Nutritional Quality}

In general, drought reduces both nutrient uptake by roots and transport of nutrients from the roots to the shoots because of decreased nutrient diffusion in the growing media due to a lack of moisture and lower transpiration rates in the crops from drought stress [154-157]. These effects, therefore, contributed to the significantly lower levels of $\mathrm{N}, \mathrm{P}$, and $\mathrm{K}$ found in all lettuce crops which underwent a drought period $(p<0.01)$. Because plants require much lower levels of micronutrients in general, the effects of drought stress do not influence micronutrient concentrations as severely as macronutrients [158]; this is likely why reductions in the concentrations of most micronutrients were not observed in the droughted lettuce.

Because of the similar or higher micronutrient levels of lettuce grown in droughted almond shells compared to droughted perlite, as well as the almond shell media's remarkable ability to retain water at low potentials over time, this shows that the almond shell media could be used to maintain the nutritional quality of hydroponically-produced crops in cases of water shortages, provided yield can be increased after amending EC levels of the substrate. While lettuce grown in PDPs under drought had consistently high levels of all nutrients, this media could not be used to maintain production under drought conditions due to the material's low water-holding capacity, resulting in extremely reduced yields. 


\section{Conclusions}

Hydroponics offers an innovative technological solution for sustainable agriculture, preserving soil resources whilst building food self-sufficiency in areas with limited available agricultural land, such as urban areas and arid regions. There are opportunities to increase the sustainability of hydroponic systems by identifying locally-available waste sources that can be repurposed into valuable products and used as feedstocks for soilless growing media. This provides an alternative waste management strategy which supports circular economies and local food production. Soilless growing media can be used to increase the resiliency of hydroponic systems by holding water and nutrients for plants in cases of water or energy shortages. This study showed that almond shells, an agricultural waste product common in the Mediterranean, western United States, and Middle East, could provide a sustainable alternative to perlite. While yields of lettuce grown in almond shells were lower than in perlite, they were still commercially relevant. Leaching the almond shells prior to use could improve yields by lowering the EC of the growing media and thus reducing possible osmotic stress in crops. Adjusting the irrigation schedule and nutrient solution to maintain an ideal balance of water and air in the media and to eliminate any macronutrient deficiencies could also improve the yields achieved with the almond shell media. The high easily available water capacity of the almond shell media, as well as its ability to maintain low water tensions throughout drought, shows that this material would be ideal for use in areas that have limited freshwater sources. The plastic drainage plank, an innovative material engineered from recycled thermoplastics, was able to grow highly nutritious lettuce crops, although not to a commercial yield. This substrate could likely be improved by manufacturing with a higher porosity and wider pore size distribution. It is also recommended that this material be used in hydroponic systems which provide a constant water supply to plants, such as floating raft systems or nutrient film technique. If improved, the PDPs could offer an important growing media alternative, since they can be cleaned and reused almost indefinitely, which is not possible for almond shells. More research is needed to identify soilless growing media options through reuse of waste sources in different local contexts, as well as to identify ways to improve overall hydroponic system sustainability within a circular economy. In this way, hydroponics can be used to produce food with lower use of resources and build equitable, self-sufficient food systems worldwide.

Author Contributions: Conceptualization, N.K., A.P., and E.L.-C.; methodology, N.K., R.S., A.P., and E.L.-C.; validation, R.S., A.P., and E.L.-C.; formal analysis, N.K. and R.S.; investigation, N.K.; resources, N.K., R.S., A.P., and E.L.-C.; writing-original draft preparation, N.K.; writing-review and editing, N.K., R.S., A.P., and E.L.-C.; visualization, N.K.; supervision, E.L.-C.; project administration, N.K. and E.L.-C.; funding acquisition, A.P. and E.L.-C. All authors have read and agreed to the published version of the manuscript.

Funding: This research was funded by the N8 Agrifood Program Newcastle Pump Priming (No grant number available).

Acknowledgments: The main author was supported during this research by the U.S. Fulbright Program. The authors would like to thank industry partners, including Borges Andalucía and the recycled plastic drainage plank supplier, for material donations.

Conflicts of Interest: The authors declare no conflicts of interest. The funders had no role in the design of the study; in the collection, analyses, or interpretation of data; in the writing of the manuscript, or in the decision to publish the results.

\section{Appendix A}

Irrigation water was mixed with two stock nutrient solutions based on formulations for leafy greens described by Mattson and Peters [102]. The chemical characteristics of the irrigation water, after adding the stock solutions, is given in Table A1. 
Table A1. Characteristics of irrigation water with nutrient solution used for lettuce growth trial.

\begin{tabular}{cc}
\hline Parameter $^{*}$ & Irrigation Water \\
\hline $\mathrm{pH}$ & $5.60-6.00$ \\
$\mathrm{EC}\left(\mathrm{mS} \mathrm{cm}^{-1}\right)$ & $1.50-1.60$ \\
$\mathrm{~N}$ & 126 \\
$\mathrm{P}$ & 31.0 \\
$\mathrm{~K}$ & 312 \\
$\mathrm{Ca}$ & 140 \\
$\mathrm{Mg}$ & 24.4 \\
$\mathrm{~S}$ & 64.4 \\
$\mathrm{Fe}$ & 2.38 \\
$\mathrm{Mn}$ & 0.25 \\
$\mathrm{Zn}$ & 0.06 \\
$\mathrm{Mo}$ & 0.05 \\
$\mathrm{Cu}$ & 0.25 \\
$\mathrm{~B}$ & 0.05 \\
\hline
\end{tabular}

* Nutrients are reported in $\mathrm{mg} \mathrm{L}^{-1}$.

\section{Appendix B}

Perlite and almond shells were tested for chemical composition, with results displayed in Table A2.

Table A2. Chemical characteristics of perlite and almond shell media.

\begin{tabular}{ccc}
\hline Characteristic & Perlite & Almond Shells \\
\hline Total C $(\% w t / w t)$ & 0.14 & 52.1 \\
Total N $(\% w t / w t)$ & 0.44 & 1.09 \\
Total Soluble N $\left(\mathrm{g} \mathrm{kg}^{-1}\right)$ & 0.11 & 0.18 \\
$\mathrm{NH}_{4}^{+}\left(\mathrm{g} \mathrm{kg}^{-1}\right)$ & 0.09 & 0.18 \\
$\mathrm{NO}_{3}^{-}\left(\mathrm{g} \mathrm{kg}^{-1}\right)$ & $<0.028$ & $<0.004$ \\
$\mathrm{P}\left(\mathrm{g} \mathrm{kg}^{-1}\right)$ & $<0.047$ & 0.19 \\
$\mathrm{~K}^{\left(\mathrm{g} \mathrm{kg}^{-1}\right)}$ & 0.07 & 6.43 \\
$\mathrm{Ca}\left(\mathrm{g} \mathrm{kg}^{-1}\right)$ & 0.03 & 0.35 \\
$\mathrm{Mg}\left(\mathrm{g} \mathrm{kg}^{-1}\right)$ & $<0.009$ & 0.13 \\
$\mathrm{~S}\left(\mathrm{~g} \mathrm{~kg}^{-1}\right)$ & 0.17 & 0.09 \\
$\mathrm{Na}\left(\mathrm{g} \mathrm{kg}^{-1}\right)$ & 0.13 & 0.15 \\
$\mathrm{Cl}\left(\mathrm{g} \mathrm{kg}^{-1}\right)$ & 0.09 & 0.37 \\
Fe $\left(\mathrm{mg} \mathrm{kg}^{-1}\right)$ & 3.0 & 8.0 \\
$\mathrm{Mn}\left(\mathrm{mg} \mathrm{kg}^{-1}\right)$ & $<0.4$ & 3.0 \\
$\mathrm{Cu}\left(\mathrm{mg} \mathrm{kg}^{-1}\right)$ & $<0.4$ & 1.0 \\
$\mathrm{Zn}\left(\mathrm{mg} \mathrm{kg}^{-1}\right)$ & $<0.9$ & 2.0 \\
$\mathrm{~B}\left(\mathrm{mg} \mathrm{kg}^{-1}\right)$ & 2.3 & 9.0 \\
\hline
\end{tabular}

\section{Appendix C}

The particle size distribution of the milled (fine texture) and blended (coarse texture) almond shells are provided in Figure A1. The coarseness index was $45.2 \%$ for milled and $79.1 \%$ for blended almond shells. These were mixed in equal volumes to make the final almond shell media used in this study. 


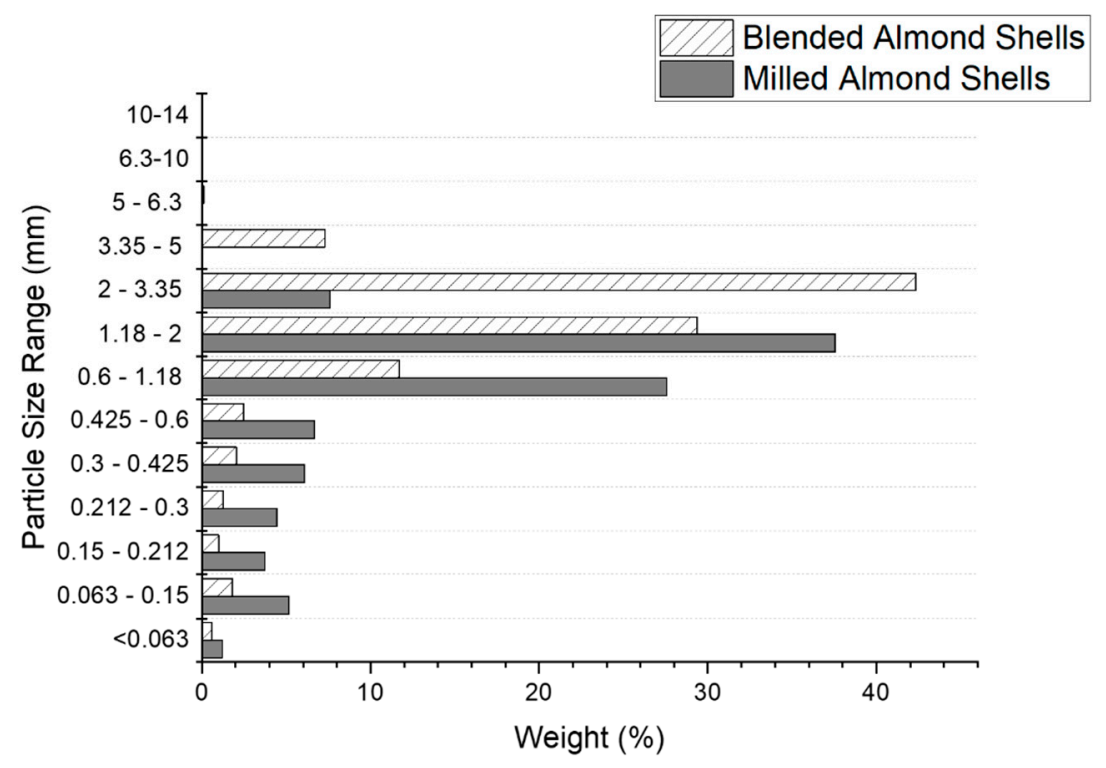

Figure A1. Particle size distribution of blended and milled almond shells.

\section{Appendix D}

Additional data taken during and after the induced drought period are provided in Appendix D, showing stomatal conductance (Figure A2), leaf surface temperatures (Figure A3), and matric potential readings (Figure A4).

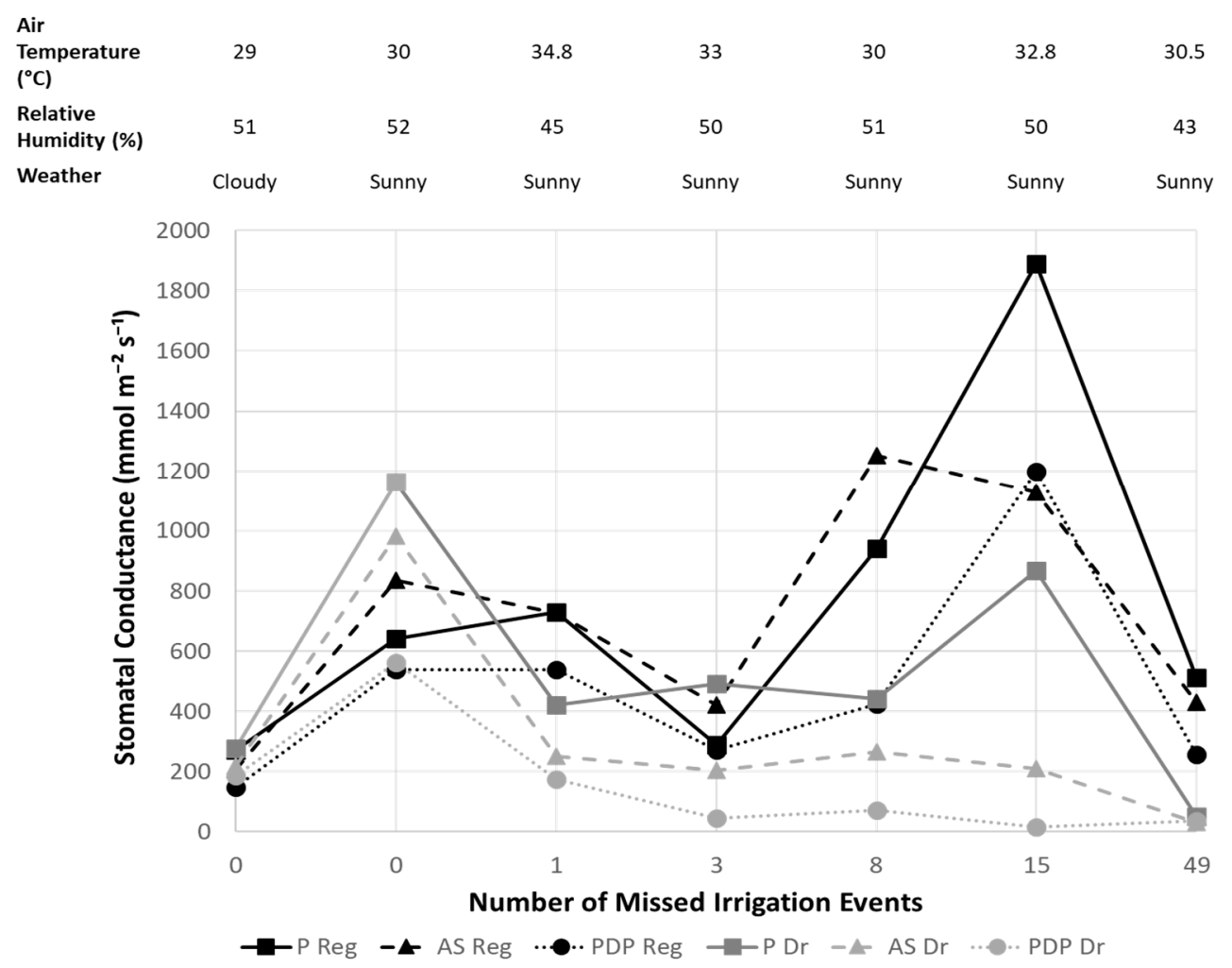

Figure A2. Stomatal conductance readings taken during induced drought period. 


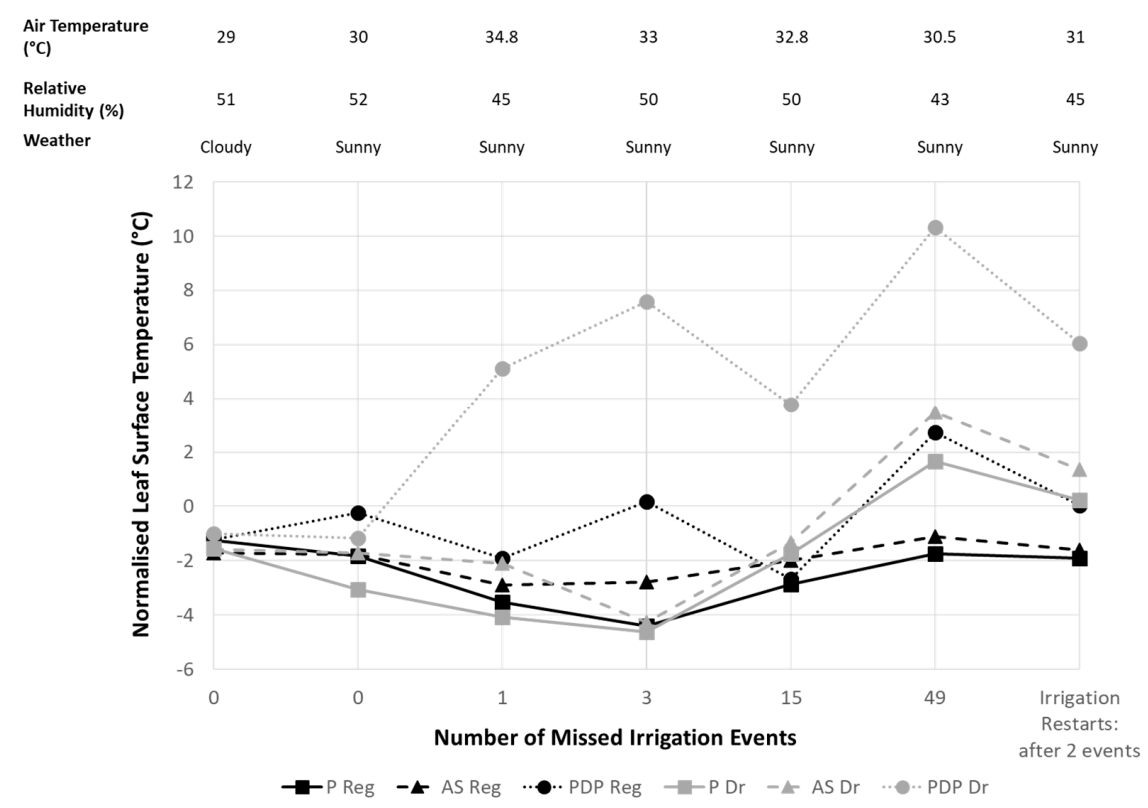

Figure A3. Normalised leaf surface temperature readings taken during induced drought period.

Date

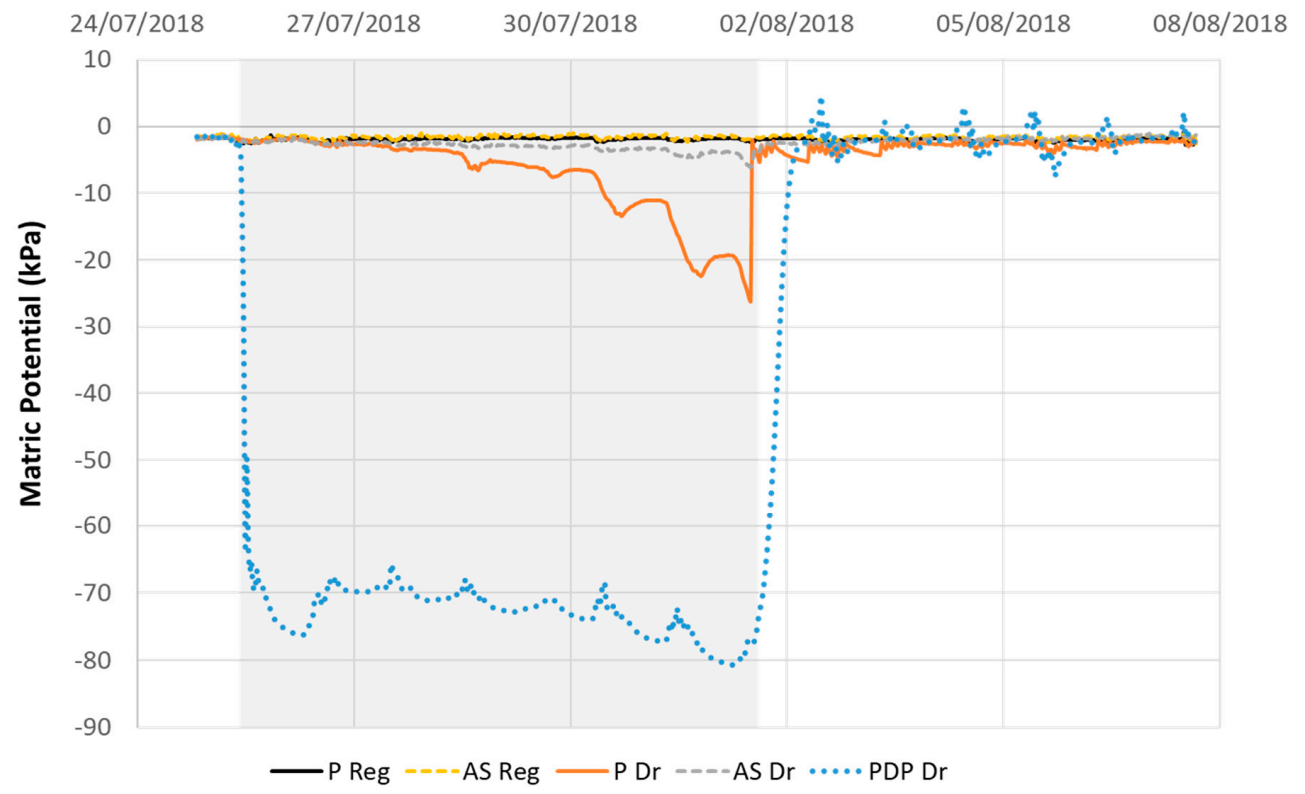

Figure A4. Tensiometer readings during and after drought. The drought period is indicated on the graph with grey shading, with drought starting on 25 July 2018 and ending on 1 August 2018.

\section{References}

1. Wang, W.; Vinocur, B.; Altman, A. Plant responses to drought, salinity and extreme temperatures: Towards genetic engineering for stress tolerance. Planta 2003, 218, 1-14. [CrossRef]

2. Vermeulen, S.J.; Campbell, B.; Ingram, J.S. Climate Change and Food Systems. Annu. Rev. Environ. Resour. 2012, 37, 195-222. [CrossRef]

3. Bernard, B.; Lux, A. How to feed the world sustainably: An overview of the discourse on agroecology and sustainable intensification. Reg. Environ. Chang. 2017, 17, 1279-1290. [CrossRef]

4. Hayes, T.B.; Hansen, M. From silent spring to silent night: Agrochemicals and the anthropocene. Elem. Sci. Anth. 2017, 5, 57. [CrossRef] 
5. Savvas, D. Hydroponics: A modern technology supporting the application of integrated crop management in greenhouse. J. Food Agric. Environ. 2003, 1, 80-86.

6. Molden, D. Water for Food, Water for Life: A Comprehensive Assessment of Water Management in Agriculture; International Water Management Institute: London, UK, 2007.

7. Muller, A.; Ferré, M.; Engel, S.; Gattinger, A.; Holzkämper, A.; Huber, R.; Muller, M.; Six, J. Can soil-less crop production be a sustainable option for soil conservation and future agriculture? Land Use Policy 2017, 69, 102-105. [CrossRef]

8. Bradley, P.; Marulanda, C. Simplified hydroponics to reduce global hunger. Acta Hortic. 2001, 554, $288-296$. [CrossRef]

9. Orsini, F.; Kahane, R.; Nono-Womdim, R.; Gianquinto, G. Urban agriculture in the developing world: A review. Agron. Sustain. Dev. 2013, 33, 695-720. [CrossRef]

10. Lee, S.; Lee, J. Beneficial bacteria and fungi in hydroponic systems: Types and characteristics of hydroponic food production methods. Sci. Hortic. (Amst.) 2015, 195, 206-215. [CrossRef]

11. Sheikh, B.A. Hydroponics: Key to sustain agriculture in water stressed and urban environment. Pak. J. Agric. Agric. Eng. Vet. Sci. 2006, 22, 53-57.

12. FAO. Food for the Cities. Available online: www.fao.org/fcit (accessed on 9 September 2018).

13. Specht, K.; Siebert, R.; Hartmann, I.; Freisinger, U.B.; Henckel, D.; Walk, H.; Dierich, A. Urban agriculture of the future: An overview of sustainability aspects of food production in and on buildings. Agric. Hum. Values 2014, 31, 33-51. [CrossRef]

14. Despommier, D. The vertical farm: Controlled environment agriculture carried out in tall buildings would create greater food safety and security for large urban populations. J. Consum. Prot. Food Saf. 2011, 6, 233-236. [CrossRef]

15. De Zeeuw, H.; van Veenhuizen, R.; Dubbeling, M. The role of urban agriculture in building resilient cities in developing countries. J. Agric. Sci. 2011, 149, 153-163. [CrossRef]

16. Eigenbrod, C.; Gruda, N. Urban vegetable for food security in cities. A review. Agron. Sustain. Dev. 2015, 35, 483-498. [CrossRef]

17. Tyson, R.V.; Treadwell, D.D.; Simonne, E.H. Opportunities and Challenges to Sustainability in Aquaponic Systems. Horttechnology 2011, 21, 6-13. [CrossRef]

18. Barbosa, G.L.; Gadelha, F.D.A.; Kublik, N.; Proctor, A.; Reichelm, L.; Weissinger, E.; Wohlleb, G.; Halden, R. Comparison of Land, Water, and Energy Requirements of Lettuce Grown Using Hydroponic vs. Conventional Agricultural Methods. Int. J. Environ. Res. Public Health 2015, 12, 6879-6891. [CrossRef]

19. Resh, H.M. Hydroponic Food Production: A Definitive Guidebook for the Advanced Home Gardener and the Commercial Hydroponic Grower; CRC Press: Boca Raton, FL, USA, 2013.

20. Caron, J.; Nkongolo, N.V. Assessing Gas Diffusion Coefficients in Growing Media from in situ Water Flow and Storage Measurements. Vadose Zone. J. 2004, 3, 300-311. [CrossRef]

21. Assouline, S.; Möller, M.; Furman, A.; Narkis, K.; Silber, A. Impact of Water Regime and Growing Conditions on Soil-Plant Interactions: From Single Plant to Field Scale. Vadose Zone. J. 2012, 11, vzj2012.0006. [CrossRef]

22. Blok, C.; Jackson, B.E.; Guo, X.; de Visser, P.H.B.; Marcelis, L.F.M. Maximum Plant Uptakes for Water, Nutrients, and Oxygen Are Not Always Met by Irrigation Rate and Distribution in Water-based Cultivation Systems. Front. Plant Sci. 2017, 8, 562. [CrossRef]

23. Papadopoulos, A.P.; Bar-Tal, A.; Silber, A.; Saha, U.K.; Raviv, M. Inorganic and Synthetic Organic Components of Soilless Culture and Potting Mixes. In Soilless Culture Theory and Practice; Raviv, M., Lieth, J.H., Eds.; Elsevier: London, UK, 2008; pp. 505-543.

24. Maher, M.; Prasad, M.; Raviv, M. Organic Soilless Media Components. In Soilless Culture Theory and Practice; Raviv, M., Lieth, J.H., Eds.; Elsevier: London, UK, 2008; pp. 459-504.

25. Raviv, M.; Wallach, R.; Silber, A.; Bar-Tal, A. Substrates and their analysis. In Hydroponic Production of Vegetables and Ornamentals; Savvas, D., Passam, H., Eds.; Embryo Publications: Athens, Greece, 2002; pp. 25-102.

26. Olle, M.; Ngouajio, M.; Siomos, A. Vegetable quality and productivity as influenced by growing medium: A review. Agriculture 2012, 99, 399-408.

27. Bilderback, T.E.; Warren, S.L.; Owen, J.S.; Albano, J.P. Healthy Substrates Need Physicals Too! Horttechnology 2005, 15, 747-751. [CrossRef] 
28. Mazuela, P.; Urrestarazu, M.; Bastias, E. Vegetable Waste Compost Used as Substrate in Soilless Culture. In Crop Production Technologies; Sharma, P., Ed.; InTech: Rijeka, Croatia, 2012; pp. 179-198, ISBN 978-953-307-787-1.

29. Pignata, G.; Casale, M.; Nicola, S. Advances in Research on Fertilization Management of Vegetable Crops; Springer: Cham, Switzerland, 2017; ISBN 978-3-319-53624-8.

30. Grillas, S.; Lucas, M.; Bardopoulou, E.; Sarafopoulos, S.; Voulgari, M. Perlite based soilless culture systems: Current commercial applications and prospects. Acta Hortic. 2001, 548, 105-114. [CrossRef]

31. Gruda, N.; Qaeyouti, M.M.; Leonardi, C. Growing media. In Good Agricultural Practices for Greenhouse Vegetable Crops: Principles for Mediterranean Climate Areas; Baudoin, W., Nono-Womdim, R., Lutaladio, N., Hodder, A., Castilla, N., Leonardi, C., de Pascale, S., Qaryouti, M., Eds.; FAO: Rome, Italy, 2013; pp. 271-301.

32. Asaduzzaman, M.; Saifullah, M.; Mollick, S.R.; Hossain, M.; Halim, G.; Asao, T. Influence of Soilless Culture Substrate on Improvement of Yield and Produce Quality of Horticultural Crops. In Soilless Culture-Use of Substrates for the Production of Quality; Asaduzzaman, M., Ed.; InTech: London, UK, 2015; pp. 1-32.

33. Scott, M.; Bragg, N.; Gunn, S. Digging into composts. In Proceedings of the International Plant Propagators' Society, Carlisle, PA, USA, 1993; Volume 43, pp. 150-156.

34. Dunn, C.; Freeman, C. Peatlands: Our greatest source of carbon credits? Carbon Manag. 2011, 2, $289-301$. [CrossRef]

35. Smith, D.L. Rockwool in Horticulture; Grower Books: London, UK, 1987.

36. Hanna, H.Y. Properly Recycled Perlite Saves Money, Does Not Reduce Greenhouse Tomato Yield, and Can Be Reused for Many Years. Horttechnology 2005, 15, 342-345. [CrossRef]

37. Urrestarazu, M.; Guillén, C.; Mazuela, P.C.; Carrasco, G. Wetting agent effect on physical properties of new and reused rockwool and coconut coir waste. Sci. Hortic. (Amst.) 2008, 116, 104-108. [CrossRef]

38. Torrellas, M.; Antón, A.; López, J.C.; Baeza, E.J.; Parra, J.P.; Muñoz, P.; Montero, J.I. LCA of a tomato crop in a multi-Tunnel greenhouse in Almeria. Int. J. Life Cycle Assess. 2012, 17, 863-875. [CrossRef]

39. Acuña, R.A.; Bonachela, S.; Magán, J.J.; Marfà, O.; Hernández, J.H.; Cáceres, R. Reuse of rockwool slabs and perlite grow-bags in a low-cost greenhouse: Substrates' physical properties and crop production. Sci. Hortic. (Amst.) 2013, 160, 139-147. [CrossRef]

40. Abad, M.; Noguera, P.; Burés, S. National inventory of organic wastes for use as growing media for ornamental potted plant production: Case study in Spain. Bioresour. Technol. 2001, 77, 197-200. [CrossRef]

41. Barrett, G.E.; Alexander, P.D.; Robinson, J.S.; Bragg, N.C. Achieving environmentally sustainable growing media for soilless plant cultivation systems-A review. Sci. Hortic. (Amst.) 2016, 212, 220-234. [CrossRef]

42. Kelepesi, S.; Tzortzakis, N.G. Olive Mill Wastes-A Growing Medium Component for Seedling and Crop Production of Lettuce and Chicory. Int. J. Veg. Sci. 2009, 15, 325-339. [CrossRef]

43. Suvo, T.; Biswas, H.; Jewel, M.; Islam, M.; Khan, M. Impact of substrate on soilless tomato cultivation. Int. J. Agric. Res. Innov. Technol. 2016, 6, 82-86. [CrossRef]

44. Rosegrant, M.W.; Ringler, C.; Zhu, T. Water for Agriculture: Maintaining Food Security under Growing Scarcity. Annu. Rev. Environ. Resour. 2009, 34, 205-222. [CrossRef]

45. Gasper, R.; Blohm, A.; Ruth, M. Social and economic impacts of climate change on the urban environment. Curr. Opin. Environ. Sustain. 2011, 3, 150-157. [CrossRef]

46. Zulfiqar, F.; Allaire, S.E.; Akram, N.A.; Méndez, A.; Younis, A.; Peerzada, A.M.; Shaukat, N.; Wright, S.R. Challenges in organic component selection and biochar as an opportunity in potting substrates: A review. J. Plant Nutr. 2019, 42, 1386-1401. [CrossRef]

47. Jurgilevich, A.; Birge, T.; Kentala-Lehtonen, J.; Korhonen-Kurki, K.; Pietikäinen, J.; Saikku, L.; Schösler, H. Transition towards Circular Economy in the Food System. Sustainability 2016, 8, 69. [CrossRef]

48. Lao, M.T.; Jiménez, S. Evaluation of almond shell as a culture substrate for ornamental plants. II. Ficus benjamina. Øyt. Int. J. Exp. Bot. 2004, 53, 79-84.

49. Urrestarazu, M.; Martínez, G.A.; Salas, M.D.C. Almond shell waste: Possible local rockwool substitute in soilless crop culture. Sci. Hortic. (Amst.) 2005, 103, 453-460. [CrossRef]

50. Chimonidou, D.; Kerkides, P.; Psyhoyiou, M.; Vassiliou, L. Rose cultivation in Cyprus under two irrigation regimes using local substrates. In Water Saving in Mediterranean Agriculture and Future Research Needs; Lamaddalena, N., Bogliotti, C., Todorovic, M., Scardigno, A., Eds.; CIHEAM: Bari, Italy, 2007; pp. 333-336.

51. Valverde, M.; Madrid, R.; García, A.L.; del Amor, F.M.; Rincón, L. Use of almond shell and almond hull as substrates for sweet pepper cultivation. Effects on fruit yield and mineral content. Span. J. Agric. Res. 2013, 11, 164-172. [CrossRef] 
52. Özenç, D.B. Effects of Composted Hazelnut Husk On Growth of Tomato Plants. Compost. Sci. Util. 2006, 14, 271-275. [CrossRef]

53. Özenç, D.B. Growth and Transpiration of Tomato Seedlings Grown in Hazelnut Husk Compost Under Water-Deficit Stress. Compost. Sci. Util. 2008, 16, 125-131. [CrossRef]

54. Dede, O.H.; Dede, G.; Ozdemir, S.; Abad, M. Physicochemical characterization of hazelnut husk residues with different decomposition degrees for soilless growing media preparation. J. Plant Nutr. 2011, 34, 1973-1984. [CrossRef]

55. Dede, O.H.; Dede, G.; Ozdemir, S. The use of hazelnut husk and biosolid in substrate preparation for ornamental plants. Afr. J. Agric. Res. 2012, 7, 5837-5841. [CrossRef]

56. Dede, O.H.; Ozdemir, S. Development of nutrient-rich growing media with hazelnut husk and municipal sewage sludge. Environ. Technol. 2017, 39, 2223-2230. [CrossRef] [PubMed]

57. Raviv, M.; Medina, S.; Krassnovsky, A.; Laor, Y.; Aviani, I. Composting olive mill waste and assessment of its horticultural value. Acta Hortic. 2009, 819, 353-360. [CrossRef]

58. Sofiadou, E.; Tzortzakis, N.G. Olive Mill Waste as a Substitute Growing Medium Component in Tomato Seedling and Crop Production. Int. J. Veg. Sci. 2012, 18, 272-283. [CrossRef]

59. Bustamante, M.A.; Moral, R.; Paredes, C.; Pe, A.; Pe, M.D. Agrochemical characterisation of the solid by-products and residues from the winery and distillery industry. Waste Manag. 2008, 28, 372-380. [CrossRef]

60. Shinohara, Y.; Hata, T.; Maruo, T.; Hohjo, M.; Ito, T. Chemical and physical properties of the Coconut-Fibre substrate and the growth and productivity of Tomato (Lycopersicon esculentum Mill.) plants. Acta Hortic. 1999, 481, 145-150. [CrossRef]

61. Evans, M.R.; Gachukia, M. Fresh Parboiled Rice Hulls Serve as an Alternative to Perlite in Greenhouse Crop Substrates. HortScience 2004, 39, 232-235. [CrossRef]

62. Gómez, C.; Robbins, J. Pine Bark Substrates Amended with Parboiled Rice Hulls: Physical Properties and Growth of Container-grown Spirea during Long-term Nursery Production. HortScience 2011, 46, 784-790. [CrossRef]

63. Bilderback, T.E.; Fonteno, W.C.; Johnson, D.R. Physical properties of media composed of peanut hulls, pine bark, and peat moss and their effects on azalea growth. J. Am. Soc. Hortic. Sci. 1982, 107, 522-525.

64. Altland, J. Use of processed biofuel crops for nursery substrates. J. Environ. Hortic. 2010, 28, 129-134.

65. Tzortzakis, N.G.; Economakis, C.D. Shredded Maize Stems as an Alternative Substrate Medium: Effect on Growth, Flowering and Yield of Tomato in Soilless Culture. J. Veg. Sci. 2005, 11, 57-70. [CrossRef]

66. Tzortzakis, N.G.; Economakis, C.D. Impacts of the substrate medium on tomato yield and fruit quality in soilless cultivation. Hortic. Sci. 2008, 35, 83-89. [CrossRef]

67. López-Baltazar, J.; Méndez-Matías, A.; Pliego-Marín, L.; Aragón-Robles, E.; Robles-Martínez, M.L. Agronomic evaluation of substrates in pepper seedlings "onza" (Capsicum annuum) in greenhouse. Rev. Mex. Cienc. Agrícolas 2013, 6, 1139-1150.

68. Jayasinghe, G.Y.; Tokashiki, Y.; Kitou, M.; Kinjo, K. Oil palm waste and synthetic zeolite: An alternative soil-less growth substrate for lettuce production as a waste management practice. Waste Manag. Res. 2008, 26, 559-565. [CrossRef]

69. Górecki, R.S.; Górecki, M.T. Utilization of waste wool as substrate amendment in pot cultivation of tomato, sweet pepper, and eggplant. Pol. J. Environ. Stud. 2010, 19, 1083-1087.

70. Dannehl, D.; Suhl, J.; Ulrichs, C.; Schmidt, U. Evaluation of substitutes for rock wool as growing substrate for hydroponic tomato production. J. Appl. Bot. Food Qual. 2015, 88, 68-77. [CrossRef]

71. Karakaş, C.; Özçimen, D.; İnan, B. Potential use of olive stone biochar as a hydroponic growing medium. J. Anal. Appl. Pyrolysis 2017, 125, 17-23. [CrossRef]

72. FAO. FAOSTAT. Available online: http://www.fao.org/faostat/en/\#data/QC (accessed on 9 September 2018).

73. Tüzel, Y.; Gül, A.; Tüzel, I.H.; Öztekin, G.B. Different Soilless Culture Systems and Their Management. J. Agric. Food Environ. Sci. 2019, 73, 7-12.

74. García-García, M.C.; Céspedes, A.J.; Lorenzo, P.; Pérez-Parra, J.J.; Escudero, M.C.; Sánchez-Guerrero, M.C.; Medrano, E.; Baeza, E.; López, J.C.; Magán, J.J.; et al. El sistema de Producción Hortícola Protegido de la Provincia de Almería; García-García, M.C., Céspedes López, A.J., Pérez Parra, J.J., Lorenzo Mínguez, P., Eds.; IFAPA: Almería, Spain, 2016.

75. Urrestarazu, M.; Mazuela, P.C.; Martínez, G.A. Effect of Substrate Reutilization on Yield and Properties of Melon and Tomato Crops. J. Plant Nutr. 2008, 31, 2031-2043. [CrossRef] 
76. Benoit, F.; Ceustermans, N. The use of recycled polyurethane (PUR) as an ecological growing medium. Plasticulture 1990, 4, 41-48.

77. Hardgrave, M. An evaluation of polyurethane foam as a reusable substrate for hydroponic cucumber production. Acta Hortic. 1995, 401, 201-208. [CrossRef]

78. Otorres, A.; Soto Zarazua, G.M. Potassium Acrylate: A novelty in hydroponic substrates. In Proceedings of the 2017 XIII International Engineering Congress (CONIIN), Santiago de Queretaro, Mexico, 15-19 May 2017; pp. 1-8.

79. Mickovski, S.B.; Buss, K.; McKenzie, B.M.; Sökmener, B. Laboratory study on the potential use of recycled inert construction waste material in the substrate mix for extensive green roofs. Ecol. Eng. 2013, 61, 706-714. [CrossRef]

80. Korol, E.; Shushunova, N. Benefits of a Modular Green Roof Technology. Procedia Eng. 2016, 161, $1820-1826$. [CrossRef]

81. Boneta, A.; Rufí-Salís, M.; Ercilla-Montserrat, M.; Gabarrell, X.; Rieradevall, J. Agronomic and environmental assessment of a polyculture rooftop soilless urban home garden in a mediterranean city. Front. Plant Sci. 2019, 10, 1-11. [CrossRef]

82. BSI. Soil Improvers and Growing Media. Sample Preparation for Chemical and Physical Tests, Determination of Dry Matter Content, Moisture Content and Laboratory Compacted Bulk Density; British Standards Institution: London, UK, 2007; BS EN 13040:2007, ISBN 978-0-580-54504-7.

83. BSI. Soil Improvers and Growing Media. Determination of Physical Properties. Dry Bulk Density, Air Volume, Water Volume, Shrinkage Value and Total Pore Space; British Standards Institution: London, UK, 2011; BS EN 13041:2011, ISBN 978-0-580-68728-0.

84. Bunt, A.C. Media and Mixes for Container-Grown Plants, 2nd ed.; Unwin Hyman Ltd: London, UK, 1988.

85. Nimmo, J.R. Porosity and Pore Size Distribution. In Encyclopedia of Soils in the Environment; Hillel, D., Ed.; Elsevier: London, UK, 2004; pp. 295-303.

86. Wallach, R. Physical Characteristics of Soilless Media. In Soilless Culture Theory and Practice; Raviv, M., Lieth, J.H., Eds.; Elsevier: London, UK, 2008; pp. 41-116.

87. BSI. Methods of Test for Soils for Civil Engineering Purposes —Part 2: Classification Tests; British Standards Institution: London, UK, 1990; BS 13772:1990; ISBN 0-580-17867-6.

88. Richards, D.; Lane, M.; Beardsell, D.V. The influence of particle-size distribution in pinebark:sand:brown coal potting mixes on water supply, aeration and plant growth. Sci. Hortic. (Amst.) 1986, 29, 1-14. [CrossRef]

89. ADAS. The Analysis of Agricultural Materials: A Manual of the Analytical Methods Used by the Agricultural Development and Advisory Service/Ministry of Agriculture, Fisheries and Food; Her Majesty's Office: London, UK, 1981.

90. Schindler, U.; Müller, L. Simplifying the evaporation method for quantifying soil hydraulic properties. J. Plant Nutr. Soil Sci. 2006, 169, 623-629. [CrossRef]

91. De Boodt, M.; Verdonck, O. The Physical Properties of the Substrates in Horticulture. Acta Hortic. 1972, 26, 37-44. [CrossRef]

92. McKenzie, N.J.; Green, T.W.; Jacquier, D.W. Laboratory measurement of hydraulic conductivity. In Soil Physical Measurement and Interpretation for Land Evaluation; McKenzie, N.J., Coughlan, K.L., Cresswell, H.P., Eds.; CSIRO Publishing: Melbourne, Australia, 2002; pp. 150-162.

93. AOAC. Method 949.12. In Official Methods of Analysis of the AOAC, 15th ed.; Association of Official Analytical Chemists: Arlington, VA, USA, 1990; ISBN 0-935584-42-0.

94. U.S. EPA. EPA-600/4-79-020, Method 350.1. Colorimetric Automated Phenate. In Methods for Chemical Analysis of Water and Wastes; United States Environmental Protection Agency Office of Research and Development: Washington, DC, USA, 1984.

95. BSI. Soil Improvers and Growing Media. Determination of Organic Matter Content and Ash; British Standards Institution: London, UK, 2011; BS EN 13039:2011, ISBN 978-0-580-68881-2.

96. The Standing Committee of Analysts. Determination of the $\mathrm{pH}$ value of sludge, soil, mud and sediment; and lime requirement of soil. In Methods for the Examination of Waters and Associated Materials; The Standing Committee of Analysts: London, UK, 1977; ISBN 0-11-751252-4.

97. Peters, J. Recommended Methods of Manure Analysis A3769; Cooperative Extension Publishing: Madison, WI, USA, 2003. 
98. The Standing Committee of Analysts. The Measurement of Electrical Conductivity and the Laboratory Determination of the $\mathrm{pH}$ Value of Natural, Treated and Waste Waters. In Methods for the Examination of Waters and Associated Materials; The Standing Committee of Analysts: London, UK, 1978; ISBN 0-11-751428-4.

99. Brechner, M.; Both, A.J. Cornell Controlled Environment Agriculture Hydroponic Lettuce Handbook; Cornell University CEA Program: Ithaca, NY, USA, 2014.

100. Goto, R. A cultura da alface. In Produção de Hortaliças em Ambiente Protegido: Condições Subtropicais; Goto, R., Tivelli, S.W., Eds.; FUNESP: São Paulo, Brazil, 1998; pp. 137-159.

101. BBC UK Heatwave: Lettuce Growers Warn of Imminent Shortage. Available online: https://www.bbc.co.uk/ news/business-44664834 (accessed on 10 September 2018).

102. Mattson, N.S.; Peters, C. A Recipe for Hydroponic Success. In insideGROWER; Ball Publishing: Chicago, IL, USA, 2014; pp. 16-19.

103. Prashar, A.; Jones, H. Infra-Red Thermography as a High-Throughput Tool for Field Phenotyping. Agronomy 2014, 4, 397-417. [CrossRef]

104. Fox, J. The R Commander: A Basic Statistics Graphical User Interface to R. J. Stat. Softw. 2005, 14, 1-42. [CrossRef]

105. R Core Team. R: A language and Environment for Statistical Computing; R Foundation for Statistical Computing: Vienna, Austria, 2017.

106. Pinheiro, J.; Bates, D.; DebRoy, S.; Sarkar, D. nlme: Linear and Nonlinear Mixed Effects Models. R Package Version 3.1-131.1.; R Core Team: Vienna, Austria, 2018.

107. Abad, M.; Martinez-Herrero, M.D.; Martinez Garcia, J.; Martinez, C. Evaluacion agronomica de los sustratos de cultivo (Agricultural evaluation of crop media). Actas Hortic. 1993, 11, 141-154.

108. Bik, R.A. Substrates in Floriculture. In Proceedings of the XXI International Horticultural Congress, Hamburg, Germany, 29 Augus-4 September 1982; Instituut voor Bodemvruchtbaarheid: Hambourg, Germany, 1983; pp. 811-883.

109. Boertje, G.A. Physical laboratory analyses of potting composts. Acta Hortic. 1984, 150, 47-50. [CrossRef]

110. Raviv, M.; Chen, Y.; Inbar, Y. Peat and peat substitutes as growth media for container grown plants. In The Role of Organic Matter in Modern Agriculture; Chen, Y., Avnimelech, Y., Eds.; Martinus Nijhoff Publishers: Dordrecht, Netherlands, 1986; pp. 257-287.

111. Drzal, M.S.; Fonteno, W.C.; Cassel, D.K. Pore fraction analysis: A new tool for substrate testing. Acta Hortic. 1999, 481, 43-53. [CrossRef]

112. Gruda, N.; Schnitzler, W.H. Suitability of wood fiber substrate for production of vegetable transplants. Sci. Hortic. (Amst.) 2004, 100, 309-322. [CrossRef]

113. Handreck, K.A. Particle size and the physical properties of growing media for containers. Commun. Soil Sci. Plant Anal. 1983, 14, 209-222. [CrossRef]

114. Noguera, P.; Abad, M.; Puchades, R.; Maquieira, A.; Noguera, V. Influence of Particle Size on Physical and Chemical Properties of Coconut Coir Dust as Container Medium. Commun. Soil Sci. Plant Anal. 2003, 34, 593-605. [CrossRef]

115. Samadi, A. Effect of Particle Size Distribution of Perlite and its Mixture with Organic Substrates on Cucumber in Hydroponics System. J. Agric. Sci. Technol. 2011, 13, 121-129.

116. Obidiegwu, J.E.; Bryan, G.J.; Jones, H.G.; Prashar, A. Coping with drought: Stress and adaptive responses in potato and perspectives for improvement. Front. Plant Sci. 2015, 6, 542. [CrossRef]

117. Fuchs, M. Infrared measurement of canopy temperature and detection of plant water stress. Theor. Appl. Climatol. 1990, 42, 253-261. [CrossRef]

118. Prashar, A.; Jones, H.G. Assessing Drought Responses Using Thermal Infrared Imaging. In Environmental Responses in Plants; Duque, P., Ed.; Springer: New York, NY, USA, 2016; pp. 209-219.

119. Anderson, D.R. Thermal Conductivity of Polymers. Chem. Rev. 1966, 66, 677-690. [CrossRef]

120. Oriol, F.; De Boodt, M.; Verdonck, O.; Cappaert, I. Thermal properties of two organic (peat, pine bark) and two inorganic (perlite, clay) horticultural substrates. Catena 1978, 5, 389-394. [CrossRef]

121. Andriolo, J.L.; Luz, G.L.D.; Witter, M.H.; Godoi, R.D.S.; Barros, G.T.; Bortolotto, O.C. Growth and yield of lettuce plants under salinity. Hortic. Bras. 2005, 23, 931-934. [CrossRef]

122. Blat, S.; Sanchez, S.; Araújo, J.; Bolonhezi, D. Desempenho de cultivares de alface crespa em dois ambientes de cultivo em sistema hidropônico (Performance of lettuce cultivars grown in two environments, in the NFT hydroponic system). Hortic. Bras. 2011, 29, 135-138. [CrossRef] 
123. Domingues, D.S.; Takahashi, H.W.; Camara, C.A.P.; Nixdorf, S.L. Automated system developed to control pH and concentration of nutrient solution evaluated in hydroponic lettuce production. Comput. Electron. Agric. 2012, 84, 53-61. [CrossRef]

124. Da Silva, J.S.; da Silva Paz, V.P.; Soares, T.M.; de Almeida, W.F.; Fernandes, J.P. Production of lettuce with brackish water in NFT hydroponic system. Semin. Ciências Agrárias 2018, 39, 947. [CrossRef]

125. Chong, C. Experiences with wastes and composts in nursery substrates. Horttechnology 2005, 15, 739-747. [CrossRef]

126. Shannon, M.C.; Grieve, C.M. Tolerance of vegetable crops to salinity. Sci. Hortic. (Amst.) 1999, 78, 5-38. [CrossRef]

127. Munns, R. Comparative physiology of salt and water stress. Plant Cell Environ. 2002, 25, 239-250. [CrossRef]

128. Eraslan, F.; Inal, A.; Savasturk, O.; Gunes, A. Changes in antioxidative system and membrane damage of lettuce in response to salinity and boron toxicity. Sci. Hortic. (Amst.) 2007, 114, 5-10. [CrossRef]

129. Albornoz, F.; Heinrich, L.J. Over fertilization limits lettuce productivity because of osmotic stress. Chil. J. Agric. Res. 2015, 75, 284-290. [CrossRef]

130. Raviv, M.; Leith, J.H. Significance of Soilless Culture in Agriculture. In Soilless Culture Theory and Practice; Raviv, M., Lieth, J.H., Eds.; Elsevier: London, UK, 2008; pp. 1-12.

131. Bardhan, S.; Chen, Y.; Dick, W.A. Recycling for Sustainability: Plant Growth Media from Coal Combustion Products, Biosolids and Compost. Int. J. Civ. Environ. Eng. 2009, 1, 177-183. [CrossRef]

132. Aghdak, P.; Mobli, M.; Khoshgoftarmanesh, A.H. Effects of different growing media on vegetative and reproductive growth of bell pepper. J. Plant Nutr. 2016, 39, 967-973. [CrossRef]

133. Linker, R.; Johnson-Rutzke, C. Modeling the effect of abrupt changes in nitrogen availability on lettuce growth, Root-shoot partitioning and nitrate concentration. Agric. Syst. 2005, 86, 166-189. [CrossRef]

134. Broadley, M.R.; Escobar-Gutierrez, A.J.; Burns, A.; Burns, I.G. What are the effects of nitrogen deficiency on growth components of lettuce? New Phytol. 2000, 147, 519-526. [CrossRef]

135. Gerard, C.J.; Sexton, P.; Shaw, G. Physical Factors Influencing Soil Strength and Root Growth. Agron. J. 1982, 74, 875-879. [CrossRef]

136. Bengough, A.G.; Mullins, C.E. Mechanical impedance to root growth: A review of experimental techniques and root growth responses. J. Soil Sci. 1990, 41, 341-358. [CrossRef]

137. Kämpf, A.N.; Allen Hammer, P.; Kirk, T. Effect of the packing density on the mechanical impedance of root media. Acta Hortic. 1999, 481, 689-694. [CrossRef]

138. Kerbiriou, P.J.; Stomph, T.J.; Van Der Putten, P.E.L.; Lammerts Van Bueren, E.T.; Struik, P.C. Shoot growth, root growth and resource capture under limiting water and $\mathrm{N}$ supply for two cultivars of lettuce (Lactuca sativa L.). Plant Soil 2013, 371, 281-297. [CrossRef]

139. Montesano, F.F.; van Iersel, M.W.; Parente, A. Timer versus moisture sensor-based irrigation control of soilless lettuce: Effects on yield, quality and water use efficiency. Hortic. Sci. 2016, 43, 67-75. [CrossRef]

140. Darnton-Hill, I.; Webb, P.; Harvey, P.W.; Hunt, J.M.; Dalmiya, N.; Chopra, M.; Ball, M.J.; Bloem, M.W.; de Benoist, B. Micronutrient deficiencies and gender: Social and economic costs. Am. J. Clin. Nutr. 2005, 81, 1198S-1205S. [CrossRef]

141. Smith, E.R. Global Nutrient Availability: A call for accountability and action. Lancet Planet. Health 2018, 2, e380-e381. [CrossRef]

142. Smith, M.R.; Myers, S.S. Impact of anthropogenic CO2 emissions on global human nutrition. Nat. Clim. Chang. 2018, 8, 834-839. [CrossRef]

143. Weyant, C.; Brandeau, M.L.; Burke, M.; Lobell, D.B.; Bendavid, E.; Basu, S. Anticipated burden and mitigation of carbon-dioxide-induced nutritional deficiencies and related diseases: A simulation modeling study. PLoS Med. 2018, 15, e1002586. [CrossRef] [PubMed]

144. Gruda, N. Do soilless culture systems have an influence on product quality of vegetables? J. Appl. Bot. Food Qual. 2009, 82, 141-147. [CrossRef]

145. Putra, P.A.; Yuliando, H. Soilless Culture System to Support Water Use Efficiency and Product Quality: A Review. Agric. Agric. Sci. Procedia 2015, 3, 283-288. [CrossRef]

146. Meagy, M.J.; Eaton, T.E.; Barker, A. V Assessment of mineral nutrient concentrations of lettuce in response to cultivar selection and fertilization in greenhouse production. J. Plant Nutr. 2016, 39, 1796-1808. [CrossRef]

147. Winsor, G.; Adams, P. Diagnosis of Mineral Disorders in Plants, Vol. 3. Glass House Crops; Her Majesty's Stationery Office: London, UK, 1987. 
148. Hakerlerler, H.; Anac, D.; Gul, A.; Saatci, N. The effects of soilless nutrients and nutrient quantities on the greenhouse conditions of soilless mediums. J. Ege Univ. Fac. Agric. 1992, 29, 87-94.

149. Trani, P.E.; Raij, B. Vegetables. In Fertilization and Liming Recommendations for the State of São Paulo; Raij, B., Cantarella, H., Quaggio, J.A., Furlani, A.M.C., Eds.; Instituto Agronômico de Campinas: Campinas, Brazil, 1996; pp. 155-203.

150. Hartz, T.K.; Johnstone, P.R.; Williams, E.; Smith, R.F. Establishing Lettuce Leaf Nutrient Optimum Ranges Through DRIS Analysis. HortScience 2007, 42, 143-146. [CrossRef]

151. Lucas, R.E.; Davis, J.F. Relationships between $\mathrm{pH}$ values of organic soils and availabilities of 12 plant nutrients. Soil Sci. 1961, 92, 177-182. [CrossRef]

152. Neocleous, D.; Koukounaras, A.; Siomos, A.S.; Vasilakakis, M. Assessing the Salinity Effects on Mineral Composition and Nutritional Quality of Green and Red “Baby" Lettuce. J. Food Qual. 2014, 37, 1-8. [CrossRef]

153. Montemurro, F.; Diacono, M.; Vitti, C.; Debiase, G. Biodegradation of olive husk mixed with other agricultural wastes. Bioresour. Technol. 2009, 100, 2969-2974. [CrossRef] [PubMed]

154. Viets, F.G.J. Water deficits and nutrient availability. In Water Deficits and Plant Growth. Vol. III: Plant Responses and Control of Water Balance; Kozlowski, T.T., Ed.; Academic Press: New York, NY, USA, 1972; pp. 217-240.

155. Pinkerton, A.; Simpson, J. Interactions of surface drying and subsurface nutrients affecting plant growth on acidic soil profiles from an old pasture. Aust. J. Exp. Agric. 1986, 26, 681-689. [CrossRef]

156. Tanguilig, V.C.; Yambao, E.B.; O'toole, J.C.; De Datta, S.K. Water stress effects on leaf elongation, leaf water potential, transpiration, and nutrient uptake of rice, maize, and soybean. Plant Soil 1987, 103, 155-168. [CrossRef]

157. Alam, S.M. Nutrient uptake by plants under stress conditions. In Handbook of Plant and Crop Stress; Pessarakli, M., Ed.; Marcel Dekker: New York, NY, USA, 1999; pp. 285-314.

158. Hu, Y.; Schmidhalter, U. Drought and salinity: A comparison of their effects on mineral nutrition of plants. J. Plant Nutr. Soil Sci. 2005, 168, 541-549. [CrossRef]

(C) 2020 by the authors. Licensee MDPI, Basel, Switzerland. This article is an open access article distributed under the terms and conditions of the Creative Commons Attribution (CC BY) license (http://creativecommons.org/licenses/by/4.0/). 